\title{
Flare Gas Recovery for Algal Protein Production
}

\author{
Colin M. Beal ${ }^{1}$, F. Todd Davidson ${ }^{2}$, Michael E. Webber², Jason C. Quinn ${ }^{3 *}$
}

${ }^{1}$ B\&D Engineering and Consulting LLC, 7419 State Hwy 789, Lander, WY 82520, United States

${ }^{2}$ The University of Texas at Austin, 1 University Station, Austin, Texas, 78712, United States

${ }^{3}$ Utah State University, 4130 Old Main Hill, Logan, Utah, United States

*Corresponding Author: Jason.Quinn@usu.edu, 435-797-0341

\begin{abstract}
Concern about the sustainable supply of energy and food for future generations has motivated researchers to investigate alternative production pathways. Algal systems represent a promising environmentally favorable production platform for fuel and protein production, however there are many barriers to commercialization, including high energy and intensive fertilizer demands. Meanwhile the volume of flared natural gas around the world has approached 140 billion cubic meters per year. This study investigates the energy return on investment (EROI) of the synergistic integration of flare gas with a microalgae biorefinery. The biorefinery modeled herein includes all sub-processes required for the coincident production of biomass and conversion to biocrude along with a protein-rich feed product. The performance of the biorefinery was estimated by conducting a mass and energy balance for all of the sub-processes. For this design, flare
\end{abstract}

Page 1 of 43

(C) 2016. This manuscript version is made available under the Elsevier user license http://www.elsevier.com/open-access/userlicense/1.0/ 
gas is utilized in a combined heat and power plant to generate heat, electricity, and ammonia for use onsite. Using this method, the baseline EROI is 159 , which is higher than conventional energy and food production systems. A life-cycle assessment indicates significant emission reductions with a total well to product emission of $-786 \mathrm{gCO}_{2 \text {-eq }} \mathrm{MJ}^{-}$ 1. Alternative accounting scenarios and sensitivities are evaluated. Results show the proposed pathway as an opportunity to utilize flare gas for the production of biofuel and protein from algae representing an environmentally beneficial system.

Keywords: Microalgae; Lifecycle Assessment; Feed; EROI; Biofuel; Biorefinery 


\section{INTRODUCTION}

Recent studies demonstrate that global protein demand is projected to increase by more than $100 \%$ by $2050[1,2]$. There are major environmental impacts associated with food production (particularly protein production) and managing these impacts as the population grows is daunting. Research shows that roughly one-third of arable land and up to three-quarters of freshwater is devoted to global food production $[3,4]$. Increasing demand from a growing global population highlights the need for the development of alternative protein sources. Agricultural production of algal biomass is a promising candidate to fill the anticipated gap between supply and demand with inherent advantages such as high productivity, suitability for non-arable land, and compatibility with low quality water [5], which are among the largest constraints for traditional crop production [6]. However, despite significant investments from government agencies and private companies [7] energy-efficient, economical, and sustainable production of algal bioproducts has yet to be demonstrated [8].

Primary limitations on algal bioproduct systems are associated with high energy and nutrient consumption in the growth phase, large energy demand for product separation in the harvesting phase, and complications associated with processing and drying wet biomass for end use [8-15]. The barriers to realizing energy efficient production of algal bioproducts include electricity demand (predominantly to supply water and carbon dioxide to the algae facility and to mix the growth volumes), heat requirements (primarily for drying biomass), and energy embedded in nutrient requirements (mainly carbon, nitrogen, and phosphorus) [9]. 
Meanwhile, significant quantities of natural gas (which is a hydrocarbon co-product of oil extraction) are disposed of every day by flaring (i.e., combustion) at production, distribution, and refining sites. It has been estimated that over 140 billion cubic meters (BCM) per year of natural gas was flared in 2012, representing 3.5\% of global production [16]. Flaring occurs when excess gas is produced during oil recovery and economical transportation routes are not available to move the gas to market. In 2014, The United States vented and flared roughly 8.5 BCM (300,000 million cubic feet (mmscf)) of natural gas at oil-and-gas production and processing facilities, which is about $1 \%$ of total US extraction [17]. Assuming a heating content of $55 \mathrm{MJ} / \mathrm{kg}$ (1033 BTU/cf) and an electricity conversion efficiency of $55 \%$, this amount of gas is sufficient to provide electricity to the entire state of Oregon [18].

Despite the apparent waste, the use of flaring helps manage logistical and safety concerns and reduces the overall environmental impact by converting methane with a global warming potential $(\mathrm{GWP})$ of 29 to carbon dioxide $(\mathrm{GWP}=1)$ [19]. In recent years, up to $30 \%$ of produced gas in the Bakken field of North Dakota was flared [20]. Recent studies used satellite instrumentation to observe flare sites around the world [16, 21]. The results revealed thousands of onshore and offshore flare sites associated with production, transportation, refining, and consumption of hydrocarbons. Some of the top flaring countries in the world include Russia, Nigeria, and Iran. As of 2012, the largest flares in the world were located near Punta de Mata, Venezuela with estimated individual flow rates of approximately $1 \mathrm{BCM}$ per year. By comparison, the United States has the largest number of flares of any country, but the vast majority of flare sites burn much less than 
$0.01 \mathrm{BCM}$ per year (the equivalent of approximately $1 \mathrm{mmscf}$ per day assuming the flare burns continuously throughout the year).

In this study, we propose using flare gas to generate electricity, heat, and nitrogen fertilizer in a novel, integrated pathway to improve the energy efficiency of algal bioproducts (i.e., biocrude and algae meal), increase global protein production, and reduce the negative environmental impacts of oil-and-gas production from flare gas combustion. The integration of algal cultivation systems with flare gas represents a potentially synergistic activity because it would mitigate environmental impacts while producing valuable commodities.

As a proof-of-principle, we use a first-order energy and mass balance approach to evaluate the energetics and life-cycle emissions of the combined system, recognizing that complete techno-economic (TEA) and additional life-cycle analyses (LCA) are needed in future work to fully characterize the feasibility of the proposed system at commercial scale. The energetics of the production system are evaluated with two metrics: 1) the energy return on investment (EROI) [22] and 2) the energy impact of protein-rich algae meal [23]. The life-cycle analysis determines the net greenhouse gas (GHG) carbon dioxide equivalent $\left(\mathrm{CO}_{2} \mathrm{eq}\right)$ emissions for the proposed system [24]. By utilizing waste flare gas, this study demonstrates the potential to simultaneously improve the EROI for algal biofuels, reduce the energy intensity of protein meal, reduce emissions, and mitigate the deleterious effects of wasted natural gas. Furthermore, this work conducts a direct comparison to previous assessments in the literature, traditional fuels, and traditional crops and livestock products. Discussion includes the potential of the proposed system, 
environmental impact of integrating flare gas with algae cultivation, and the impact of energy allocation on results for flare gas and co-product electricity.

\section{METHODS}

The analysis was completed using an engineering system model that was constructed in a modular fashion with validated sub-process models as shown in Figure 1. Sub-process models - flare gas recovery and conversion, biomass production, and biomass processing - were independently validated and integrated into the engineering system model. A single industrial processing facility is modeled that includes the delivery of flare gas from co-located oil-and-gas operations and used to operate a combined heat and power generation plant (CHP) (i.e., cogeneration), ammonia production system, algae cultivation platform, and algae processing system. This design enables convenient electricity distribution for all sub-systems and facilitates the integration of heat recovery from CHP within one site. Carbon is the limiting resource for most algae systems $[9,25$, 26], so the algal cultivation facility was sized to be 10 ha to accommodate all of the carbon dioxide produced from a flare site with a gas flow rate of 2,050 $\mathrm{m}^{3} /$ day $(72,000$ scfd). Volumetric flow rates at individual domestic flare sites can vary widely from less than $3 \mathrm{~m}^{3} /$ day $(100 \mathrm{scfd})$ to more than $28,000 \mathrm{~m}^{3} /$ day $(1,000,000 \mathrm{scfd})[20,27,28]$. Volumetric flow rates at international flare sites can exceed $270,000 \mathrm{~m}^{3} /$ day $(9,540,000$ scfd) [16]. The flare gas flow rate was chosen to represent a single moderately sized flare site or the combination of multiple smaller flare sources that can provide a dependable supply of flare gas.

A summary of the critical input parameters for the integrated model are presented in Table 1 with details on each of the sub-process models presented in the following 
sections. The engineering system model was used in conjunction with life cycle inventory data to evaluate the environmental impact of the proposed process on the metric of greenhouse gas emissions.

Table 1. Primary model parameters.

\begin{tabular}{|c|c|c|c|}
\hline & Amount & Unit & Reference \\
\hline \multicolumn{4}{|l|}{ Flare Gas Recovery } \\
\hline Volumetric Flow Rate of Flare Gas & 2,050 & $\mathrm{~m}^{3} / \mathrm{d}$ & {$[20,27,28]$} \\
\hline Flare Gas Density & 0.70 & $\mathrm{~kg} / \mathrm{m}^{3}$ & {$[28,29]$} \\
\hline Flare Gas Higher Heating Value & 55.0 & $\mathrm{MJ} / \mathrm{kg}$ & {$[28,29]$} \\
\hline Flare Gas Specific Heat Capacity & 2.22 & $\mathrm{~kJ} / \mathrm{kg}-\mathrm{K}$ & {$[28,29]$} \\
\hline Compression Ratio & 1.67 & - & Assumed \\
\hline Compressor Efficiency & 0.85 & - & {$[30]$} \\
\hline \multicolumn{4}{|l|}{ Combined Heat and Power } \\
\hline Electricity Production Efficiency & $44 \%$ & - & {$[31,32]$} \\
\hline Heat Exchange Fluid Flow Rate & 0.90 & $\mathrm{~kg} / \mathrm{s}$ & Calculated \\
\hline Heat Transfer Pumping Energy & 81.8 & $\mathrm{MJ} / \mathrm{d}$ & Calculated \\
\hline Useful Heat Production Efficiency & $43 \%$ & - & {$[31,32]$} \\
\hline Heat Recovery Efficiency & $90 \%$ & - & {$[31,32]$} \\
\hline (Net) Heat Recovery Efficiency & $38 \%$ & - & Calculated \\
\hline Overall Plant Efficiency & $82 \%$ & - & Calculated \\
\hline Flue Gas Carbon Dioxide Content & $5 \%$ & $\%$ wt. & [33] \\
\hline Flue Gas Specific Heat Cap. & 0.85 & $\mathrm{~kJ} / \mathrm{kg}-\mathrm{K}$ & [33] \\
\hline Compression Ratio & 2.50 & - & Assumed \\
\hline Compressor Efficiency & 0.85 & - & [30] \\
\hline \multicolumn{4}{|l|}{ Ammonia Production } \\
\hline Electricity Input & 0.70 & $\mathrm{MJ} / \mathrm{kg}$ ammonia & {$[34,35]$} \\
\hline Heat Input & 12.6 & $\mathrm{MJ} / \mathrm{kg}$ ammonia & {$[34,35]$} \\
\hline Water Consumption & 1.20 & $\mathrm{~kg} / \mathrm{kg}$ ammonia & {$[34,35]$} \\
\hline Flare Gas Demand & 0.45 & $\mathrm{~kg} / \mathrm{kg}$ ammonia & {$[34,35]$} \\
\hline Air Input & 1.80 & $\mathrm{~kg} / \mathrm{kg}$ ammonia & {$[34,35]$} \\
\hline Carbon Dioxide Generated & 1.18 & $\mathrm{~kg} / \mathrm{kg}$ ammonia & {$[34,35]$} \\
\hline Flue Gas Carbon Dioxide Content & $100 \%$ & $\%$ wt. & {$[34,35]$} \\
\hline Flue Gas Specific Heat Cap. & 0.85 & $\mathrm{~kJ} / \mathrm{kg}-\mathrm{K}$ & [29] \\
\hline Compression Ratio & 2.50 & - & Assumed \\
\hline Compressor Efficiency & 0.85 & - & {$[30]$} \\
\hline \multicolumn{4}{|l|}{ Algae Cultivation } \\
\hline Algae Facility Size & 10.0 & ha & Assumed \\
\hline Fraction of Facility for Cultivation & 0.80 & - & {$[9,10,14,15,36]$} \\
\hline
\end{tabular}




\begin{tabular}{|l|r|l|l|}
\hline Cultivation Surface Area & 8.0 & ha & Calculated \\
\hline Pond Volume & $16,000,000$ & $\mathrm{~L}$ & Calculated \\
\hline Mixing Energy Demand & 109 & $\mathrm{kWh} / \mathrm{ha}-\mathrm{d}$ & Calculated \\
\hline Daily Harvest Volume & $3,200,000$ & $\mathrm{~L} / \mathrm{d}$ & Calculated \\
\hline Saline Make-up Water & $1,207,00$ & $\mathrm{~L} / \mathrm{d}$ & Calculated \\
\hline Water Supply Energy & 20.0 & $\mathrm{kWh} / \mathrm{ha}-\mathrm{d}$ & Calculated \\
\hline C:N:P & $106: 16: 1$ & - & {$[37,38]$} \\
\hline Productivity & 20.0 & $\mathrm{~g}$ AFDW/m2-d & {$[8,14,36,38]$} \\
\hline Lipid Fraction & 0.25 & $\mathrm{~kg}$ lipid/kg AFDW & {$[8,14,36,38]$} \\
\hline Protein Fraction & 0.40 & $\mathrm{~kg}$ protein/kg AFDW & {$[8,14,36,38]$} \\
\hline & & & \\
\hline Algae Harvesting & & & \\
\hline Overall Harvesting Efficiency & 0.77 & - & {$[9,10,14,15,36]$} \\
\hline Pumping Electricity & 0.22 & $\mathrm{~kJ} / \mathrm{kg}$ algae & Calculated \\
\hline DAF Electricity & 431 & $\mathrm{~kJ} / \mathrm{kg}$ algae & {$[10,15]$} \\
\hline Centrifuge Electricity & 107 & $\mathrm{~kJ} / \mathrm{kg}$ algae & {$[10,15]$} \\
\hline Water Recycling & 27.4 & $\mathrm{~kJ} / \mathrm{kg}$ algae & Calculated \\
\hline Water Discharge & 84.5 & $\mathrm{~kJ} / \mathrm{kg}$ algae & Calculated \\
\hline & & & \\
\hline Bioproduct Separations & & & {$[14]$} \\
\hline Drying Heat & 7.20 & $\mathrm{MJ} / \mathrm{kg}$ algae & Calculated \\
\hline Electricity Consumption & 79.9 & $\mathrm{~kJ} / \mathrm{kg}$ algae & Calculated \\
\hline Extraction Heat Consumption & 864 & $\mathrm{~kJ} / \mathrm{kg}$ algae & Calculated \\
\hline Solvent Consumption & 1.22 & $\mathrm{~g} / \mathrm{kg}$ algae & {$[15]$} \\
\hline Biocrude Recovery & 0.23 & $\mathrm{~kg}$ biocrude/kg algae & {$[14]$} \\
\hline Lipid-extracted Biomass Recovery & 0.77 & $\mathrm{~kg}$ LEA/kg algae & {$[14]$} \\
\hline
\end{tabular}




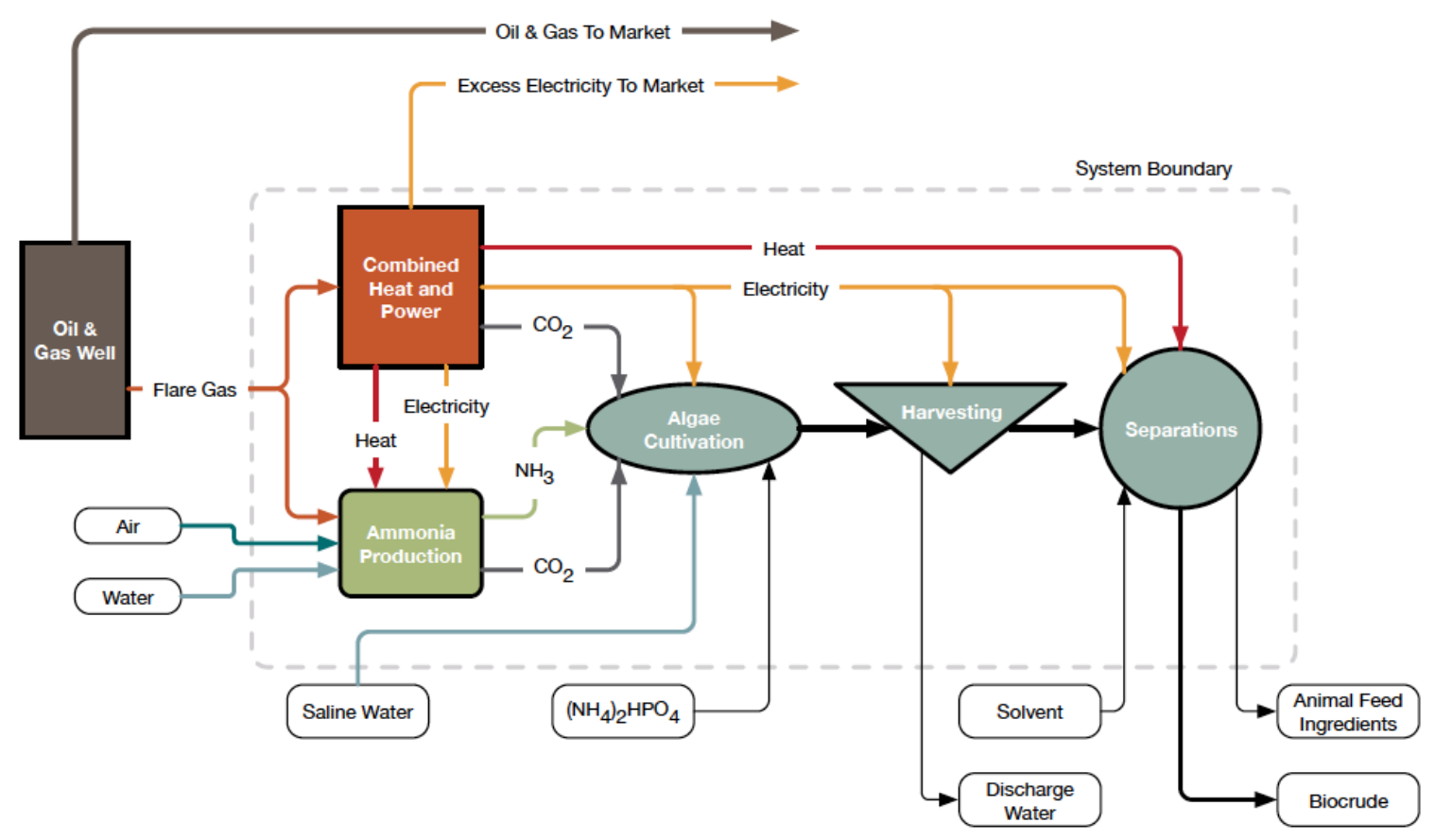

Figure 1. Baseline process flow diagram for utilizing flare gas to produce protein from algae

\subsection{Flare Gas Recovery}

For the proposed system, repurposed flare gas could be sourced for a single processing facility from multiple nearby wells to ensure a steady supply considering that the flow rates of individual wells vary. The flare gas could also be sourced from a single large facility such as a refinery or an offshore rig. The CHP plant is co-located with the oiland-gas operations and we assume the flare gas (with chemical properties of methane) is compressed isentropically for transport to the CHP plant, requiring approximately 95 $\mathrm{kJ} / \mathrm{kg}$ of gas [30]. The specific pipeline system required for an algae production facility depends on the nearby sources of flare gas and therefore varies for each site. The high density of dependable flare sites in countries such as Nigeria presents an opportunity to minimize pipelines for gas gathering. There are hundreds of potential flare gas sources in the United States, Nigeria, Venezuela, the Middle East, and elsewhere that could be 
integrated with algae production by meeting the volumetric flow rate needs described in this study $[16,21]$.

\subsection{Combined Heat and Power (Cogeneration)}

The CHP plant has a reciprocating engine and the waste heat is captured with a twophase water heat exchanger, allowing for $87 \%$ conversion to electricity and heat (i.e., 44\% useable electrical energy and 43\% useable thermal energy) [31, 32]. Thermal energy is transported through steam pipelines and the process water is recycled. The steam pipeline has an isothermal energy loss of $10 \%$, which, when combined with imperfect heat exchange yields an overall heat recovery of $38 \%$. Energy required for circulating water for heat transfer is minor $(415 \mathrm{kPa}$ pressure drop, 1.5 safety factor, and a pump efficiency of $60 \%$ ). Accounting for the water circulation energy and the thermal losses, the overall system efficiency is $82 \%$ (44\% of outgoing energy is electrical and $38 \%$ is thermal, with the balance as waste heat). The CHP plant has an electrical and thermal output capacity of $0.40 \mathrm{MW}$ and $0.39 \mathrm{MW}$, respectively. The flue gas produced from CHP is collected and transported to the algae ponds assuming isentropic compression requiring $68 \mathrm{~kJ} / \mathrm{kg}$-gas [30].

\subsection{Ammonia Production}

Ammonia production is based on the catalytic reaction of hydrogen and nitrogen (commonly referred to as the Haber-Bosch process and used worldwide) as described by Jiménez-González et al. [35], which compares closely with the process described by 
Lawrence Berkeley National Laboratory [34]. Inputs required for ammonia production include air, methane (in this case, flare gas), water, electricity, and heat. In addition to ammonia, the process generates high purity carbon dioxide. The ammonia plant was sized to provide sufficient nitrogen fertilizer for algae cultivation. The carbon dioxide generated during ammonia production is captured and used for cultivation requiring 89 $\mathrm{kJ} / \mathrm{kg}$ gas [30]. The energy requirements for the ammonia production facility were accounted for in the sizing of the CHP facility.

\subsection{Algae Cultivation}

For this proof-of-principle study, an algae production model was developed relying on the authors' prior experience with algae cultivation [38-42], leveraging prior models that contain much greater complexity $[9,10,15,43,44]$ and other highly-cited models in the literature [12-14, 45]. Appendix A presents a detailed mass balance of elements (carbon, nitrogen, and phosphorus) and biomass components (lipid, protein, carbohydrates, chlorophyll, and ash) from cultivation through harvesting and lipid extraction.

Algae are produced in open raceway ponds and the modeled facility is 10 hectares with a 0.8 packing factor to account for infrastructure. The culture is modeled as a monoculture of Desmodesmus sp. There are eight 1-ha ponds based on the design by Beal et al. [9] operated at a depth of $0.2 \mathrm{~m}$ with a bulk velocity of $0.35 \mathrm{~m} / \mathrm{s}$ delivered through a circulation device with $25 \%$ efficiency. Assuming a manning coefficient of 0.01 yields $0.16 \mathrm{~m}$ head loss $(\Delta P)$ for circulation according to the following equation provided by Lundquist et al. [14], 


$$
\Delta P=\Delta P_{c}+\Delta P_{b}+\Delta P_{S}
$$

to include head loss in the channels (c), bends (b), and sump (s). The channel head loss, $\Delta P_{c}$, is calculated as the product of channel length $(L)$ and the head loss per unit lenth $(S)$,

$$
\Delta P_{c}=L \cdot S=L \cdot \frac{\left(n^{2} \cdot V^{2}\right)}{R_{h}^{\frac{4}{3}}}[m]
$$

where $n$ is the manning coefficient, $V$ is the bulk flow velocity, and $R_{h}$ is the hydraulic radius [46]. Head loss in the bends $\left(\Delta P_{b}\right)$ and in the sump $\left(\Delta P_{s}\right)$ are estimated using the following equation,

$$
\Delta \mathrm{P}=\frac{C \cdot V^{2}}{2 \cdot g} \quad[m]
$$

where $C$ is the loss coefficient for the bends (4) or the sump (4). Under these conditions, required mixing power is $109 \mathrm{kWh} / \mathrm{ha}-\mathrm{d}$.

The annual average productivity of the system $\left(20 \mathrm{~g} / \mathrm{m}^{2}-\mathrm{d}\right)$ is based on locating the facility in southwest Texas $[12,47,48]$ and more conservative than the results published in recent experimental and modeling studies $[10,36,38]$. One fifth of the volume is harvested daily at an algal concentration of $0.5 \mathrm{~g} / \mathrm{L}$ corresponding to a nitrogen deplete growth period. Nutrient inputs are based on the Redfield ratio $(\mathrm{C}: \mathrm{N}: \mathrm{P}=106: 16: 1)$ and carbon is delivered through a sump system with an assumed $\mathrm{CO}_{2}$ uptake efficiency of $75 \%$, which is on the conservative side of values in the literature (85\% Quinn et al. [15], 79\% Beal et al. [9], 75\% Lundquist et al. [14], 95\% Davis et al. [45]). Nitrogen and phosphorus are assumed to be utilized by the algae with a $90 \%$ efficiency (based on values in the literature of 95\% Quinn et al. [15] , 100\% Beal et al. [9], 95\% Lundquist et al. [14], $80 \%$ Davis et al. [45]); the $10 \%$ loss is attributed to non-algal organisms such as 
bacteria and minor outgassing. Nitrogen is supplied from the co-located ammonium plant and phosphorous is purchased as diammonium phosphate (DAP) [9, 45]. Culture water is supplied from a saline well and recycled five times (after being recovered as supernatant during harvesting, described below) and eventually returned to the reservoir. Evaporation is modeled at $2.8 \%$ of the culture volume per day based on Beal et al. [9] (compared to literature sources of $0.9 \%$ [15], 1.8\% Lundquist et al. [14], 0.4\% Davis et al. [45]). Thus, roughly 1.2 million liters of new culture water are required each day for makeup. Water supply energy is modeled as pumping with $283 \mathrm{kPa}$ of head and $60 \%$ pump efficiency based on the water acquisition system design in Beal et al. [9].

\subsection{Harvesting}

The dewatering processes is based on a three-stage system described by Bennion et al. [10] and Quinn et al. [15]. Alternative harvesting methods exist, but have not been validated as thoroughly. For instance, several studies model the use of a filter press for dewatering [9], but it is unclear how effective a filter press will be with microalgae. Other new technologies include membrane separation [45], but experimental data has yet to be provided publicly. Pumping to and through the harvesting process is approximated with a combined head loss of $14.9 \mathrm{kPa}$ and $60 \%$ pump efficiency (authors' estimates), consuming $25 \mathrm{~J}$ per $\mathrm{L}$ processed. The primary harvesting stage is a passive bioflocculation settling step assumed to generate a maximum density of $10 \mathrm{~g} / \mathrm{L}$. Bioflocculation has been demonstrated at scale for Desmodesmus sp. [38]. The second stage is dissolved air flotation (DAF) that further dewaters the microalgae to $100 \mathrm{~g} / \mathrm{L}$,

while consuming $0.48 \mathrm{MJ}$ per $\mathrm{kg}$ of algae processed $[10,15]$. The final dewatering stage 
is a continuous clarifier (centrifuge) to remove the free water taking the system to 200 $\mathrm{g} / \mathrm{L}$, or $20 \%$ solids based on the use of an Alfa Laval machine $[10,15]$. The centrifuge requires $11.8 \mathrm{~kJ}$ per $\mathrm{L}$ processed. The harvest efficiencies of the settling, DAF, and centrifuge are assumed to be $90 \%, 90 \%$, and $95 \%$, respectively. Water recycling $(\sim 2.4$

million L per day) and water discharge ( $\sim 0.8$ million L per day) are modeled as pumping through $10 \mathrm{kPa}$ and $100 \mathrm{kPa}$ of head loss, respectively, with $60 \%$ pump efficiency (authors' estimates) - thereby requiring $17 \mathrm{~J} / \mathrm{L}$ and $167 \mathrm{~J} / \mathrm{L}$, respectively.

\subsection{Lipid Recovery and Conversion}

A variety of technologies exist for the recovery and conversion of lipids or the production of biocrude and upgrading to a fuel product $[8,11,49]$. This work assumes the lipids are separated using a solvent extraction process that is analogous to soy oil extraction that yields a protein-rich algae meal co-product, similar to soy meal $[14,38,50]$. Under normal conditions, biomass drying incurs massive energetic penalties and, as a result, the field of algal biofuels has almost entirely focused on wet extraction processes. However, due to the unique synergistic configuration proposed in this study, a surplus of heat generated by CHP can be used to dry the biomass at no energetic cost. Thus, we model drying the biomass from $20 \%$ solids to $80 \%$ solids using waste heat from CHP followed by hexane oil extraction based on the Crown IronWorks Company process described by Lundquist et al. [14]. Solvent consumption was estimated from Quinn et al. [15] for a similar process. The extraction process consumes $80 \mathrm{~kJ}$ of electricity, $860 \mathrm{~kJ}$ of heat, and $1.2 \mathrm{~g}$ of solvent per $\mathrm{kg}$ of algae processed and recovers $95 \%$ of the lipid contained in the biomass, which represents a biocrude product. The marginal remainder of the lipid is 
retained in the biomass and we assume all of the biomass is recovered as a lipid-extracted algae (LEA) product with 52\% protein content (AFDW) suitable for inclusion in animal feed products. The high protein content makes the LEA product an appealing substitute for soymeal and fishmeal in livestock feed and aquafeeds.

\subsection{Energy Return on Investment}

Energy analysis is based on the EROI, defined as the total energy output divided by the total energy input [22]. An EROI greater than 1 is desirable. The energy impacts of material and energy flows include embodied (upstream) energy associated with production and the chemical energy contained in that product. Inventory data (listed in Table 2) were collected from GREET [51] and supplemented with values from literature as needed. Co-products were assigned displacement credits according to the avoidance of conventional biocrude, animal feed, and electricity production. Estimates from Beal et al. [9] were used for the algae meal displacement credit: 3.6 MJ of non-renewable energy per $\mathrm{kg}$ of algae meal and 25.1 MJ of total energy per kg of algae meal. These estimates are based on the replacement by algae meal of a composite animal feed consisting of $75 \%$ soy meal and $25 \%$ corn meal [9].

\subsection{Energy Impact of Protein Meal}

The energy impact of animal feed ingredients quantifies the amount of energy required to produce feed components, such as corn, soy meal, fishmeal, or algae meal. Analogous to the energy impact of a fuel, this metric contains two components: embedded energy 
(which includes the energy resources consumed to produce the feed product) and chemical energy content (which is the higher heating value or caloric value of the feed itself). For the EROI analysis described above, the energy impact of algae meal was assigned based on the assumed displacement of corn and soy meal. In contrast, here, we calculate the energy impact of producing algae meal by allocating the net energy input to the integrated system among all three co-products (biocrude, algae meal, and electricity when applicable) on an energy-weighted basis. For allocation, the chemical energy content of the output products are assumed to be: $42 \mathrm{MJ} / \mathrm{kg}$ for biocrude, $21.5 \mathrm{MJ} / \mathrm{kg}$ for algae meal $[9,44,52]$ and $1 \mathrm{MJ} / \mathrm{MJ}$ for electricity.

\subsection{System Boundary and Accounting Scenarios}

The system boundary is shown in Figure 1 and includes all of the sub-processing systems outlined. The baseline analysis treats the flare gas as a waste stream with no energy value. The baseline model also assumes excess electricity can be delivered as a coproduct to the market, but assigns no value for excess heat generated. Sensitivity to these assumptions are assessed by calculating the energy and environmental impacts for three alternative scenarios: Case II) excluding the energy value of excess electricity as a coproduct, Case III) assigning the HHV of methane as the energy impact of flare gas (rather than assuming it to be 0 ), and Case IV) excluding the electricity co-product and assigning the HHV of methane to be the flare gas energy impact.

\subsection{Life Cycle Assessment}


The environmental impact of the process was assessed through a life cycle assessment of greenhouse gas emissions. The engineering system model was used as the foundation for the analysis. Energy and mass results were coupled with life cycle inventory data to evaluate the environmental impact of the scenarios outlined above. The environmental impact of the system was evaluated based on a total global warming potential. The IPCC 100 year global warming equivalency factors for carbon dioxide, methane and di-nitrogen oxide, 1, 25, and 298, respectively, where used to determine the total equivalent carbon dioxide emission for each of the scenarios outlined. Compounds contributing minor emissions from CHP (e.g., ammonia, formaldehyde, etc.) were neglected [32]. The functional unit of this study was defined as $1 \mathrm{MJ}$ of fuel for comparative purposes to other studies. Life cycle inventory data for energy and the various materials consumed in the process were sourced from GREET, NREL LCI database [51, 53], and literature. Specifically, these impacts are: $0 \mathrm{gCO}_{2-\mathrm{eq}} \mathrm{kg}^{-1}$ for water, 2,681 $\mathrm{gCO}_{2 \text {-eq }} \mathrm{kg}^{-1}$ for ammonia, $40 \mathrm{gCO}_{2 \text {-eq }} \mathrm{kg}^{-1}$ for DAP, $942 \mathrm{gCO}_{2 \text {-eq }} \mathrm{kg}^{-1}$ for hexane, and $47 \mathrm{gCO}_{2 \text {-eq }} \mathrm{MJ}^{-1}$ for heat. The system modeled has multiple products (fuel, electricity, protein, and heat) requiring an allocation of the total emissions. The excess heat produced in the system is not included as a product for life cycle accounting as it cannot realistically be exported. For the remaining products - fuel, electricity, and protein - a displacement allocation method is used. The excess electricity is assumed to displace grid electricity with an environmental impact of $700 \mathrm{gCO}_{2 \text {-eq }} \mathrm{kWhr}^{-1}$. The protein feed is assumed to displace animal feed ingredients with an environmental impact of 2,000 $\mathrm{gCO}_{2-\mathrm{eq}} \mathrm{kg}^{-1}$ [54]. Using algal biomass as a feed ingredient is an area of recent interest and widespread research $[9,55-$ 58]. Currently it is unclear which animal feed ingredients can be replaced by algal 
biomass. Further research is needed in this field to determine more specific values for the displacement credit for algal biomass as a substitute for cornmeal, soymeal, fishmeal, and possibly human food. Due to this ambiguity, the animal feed displacement credit was selected as a generic credit for substitution as an animal feed ingredient based on data by González et al. [54] and evaluated with sensitivity analysis. A biogenic carbon credit associated with the utilization of atmospheric carbon dioxide for algal growth is included. The system boundary for the process, as defined above, represents a well to product system boundary and does not include the transportation and distribution of the fuel or the emissions associated with the use (e.g., combustion) of the output products.

The environmental impact of four scenarios are evaluated based on the scenarios defined for the EROI analysis. Case I allocated the emissions of the flare gas combustion to the oil and gas industry and exports the excess electricity. Case II assumes the excess electricity cannot be exported. Case III assumes flare gas is being procured for the system and includes emissions for the carbon contained in the natural gas to satisfy the needs of the CHP plant. This scenario includes the exporting of the excess electricity. Case IV includes the purchasing of flare gas and assumes the excess electricity cannot be exported. All scenarios produce excess heat that is assumed to be rejected.

\section{RESULTS}

The input and output flows for the integrated model along with the associated energy impacts for those flows based on the system boundary shown in Figure 1 are presented in Table 2. A summary of the EROI and life cycle emission results for the four cases considered in this study is presented in Table 3. 
Table 2. Input (red) and output (black) flows for the unit operations shown in Figure 1. Individual Flow Impacts are associated with each material or energy flow, but the overall system is characterized according to "System Boundary Impacts," which only include flows that cross the system boundary (Figure 1). ${ }^{1}$ Case II and Case IV assume no electricity is produced as a co-product. ${ }^{2}$ Case III and Case IV assign $55 \mathrm{MJ} / \mathrm{kg}$ as the energy impact for flare gas, resulting in $115,500 \mathrm{MJ} / \mathrm{d}$ of additional energy input. ${ }^{3}$ All energy impacts were obtained from Argonne National Laboratory GREET model [51] except for the algae meal, which is from Beal et al. [9].

\begin{tabular}{|c|c|c|c|c|c|}
\hline & $\frac{\text { Amount }}{(X)}$ & $\frac{\text { Units }}{(X / d)}$ & $\frac{\frac{\text { Energy }}{\text { Impact }^{3}}}{(\mathrm{MJ} / \mathrm{X})}$ & $\frac{\frac{\text { Individual }}{\text { Flow }}}{\frac{\text { Impacts }}{(\mathrm{MJ} / \mathrm{d})}}$ & $\frac{\frac{\text { System }}{\text { Boundary }}}{\frac{\text { Impacts }}{(\mathrm{MJ} / \mathrm{d})}}$ \\
\hline \multicolumn{6}{|l|}{ Combined Heat and Power } \\
\hline (Flare Gas) & 1,435 & $\mathrm{~kg} / \mathrm{d}$ & 0.00 & 0 & $0^{2}$ \\
\hline (Flare Gas Transport to CHP) & 136 & $\mathrm{MJ} / \mathrm{d}$ & 2.34 & 318 & - \\
\hline (Heat Exchanger Pumping) & 82 & $\mathrm{MJ} / \mathrm{d}$ & 2.34 & 191 & - \\
\hline Electricity Generation & 34,727 & $\mathrm{MJ} / \mathrm{d}$ & 2.34 & 81,296 & - \\
\hline Heat Generation & 29,986 & $\mathrm{MJ} / \mathrm{d}$ & 1.18 & 35,263 & - \\
\hline Carbon Dioxide Produced & 3,749 & $\mathrm{~kg} / \mathrm{d}$ & 0.00 & 0 & - \\
\hline \multicolumn{6}{|l|}{ Ammonia Production } \\
\hline (Flare Gas) & 69 & $\mathrm{~kg} / \mathrm{d}$ & 0.00 & 0 & 0 \\
\hline (Air) & 276 & $\mathrm{~kg} / \mathrm{d}$ & 0.00 & 0 & 0 \\
\hline (Water) & 184 & $\mathrm{~kg} / \mathrm{d}$ & 0.01 & 2 & 2 \\
\hline (Electricity) & 108 & $\mathrm{MJ} / \mathrm{d}$ & 2.34 & 252 & - \\
\hline (Heat) & 1,930 & $\mathrm{MJ} / \mathrm{d}$ & 1.18 & 2,270 & - \\
\hline Ammonia Produced & 154 & $\mathrm{~kg} / \mathrm{d}$ & 38.72 & 5,951 & - \\
\hline Carbon Dioxide Produced & 181 & $\mathrm{~kg} / \mathrm{d}$ & 0.00 & 0 & - \\
\hline \multicolumn{6}{|l|}{ Cultivation } \\
\hline (Carbon Transport) & 5,127 & $\mathrm{MJ} / \mathrm{d}$ & 2.34 & 12,002 & - \\
\hline (Saline Water Supply) & 569 & $\mathrm{MJ} / \mathrm{d}$ & 2.34 & 1,332 & - \\
\hline (Circulation) & 3,139 & $\mathrm{MJ} / \mathrm{d}$ & 2.34 & 7,349 & - \\
\hline (Carbon Dioxide) & 3,911 & $\mathrm{~kg} / \mathrm{d}$ & 0.00 & 0 & - \\
\hline (Ammonia) & 154 & $\mathrm{~kg} / \mathrm{d}$ & 38.72 & 5,951 & - \\
\hline (DAP) & 36 & $\mathrm{~kg} / \mathrm{d}$ & 16.38 & 587 & 587 \\
\hline \multicolumn{6}{|l|}{ Harvesting } \\
\hline (Harvesting Processes) & 798 & $\mathrm{MJ} / \mathrm{d}$ & 2.34 & 1,867 & - \\
\hline (Water Recycling) & 41 & $\mathrm{MJ} / \mathrm{d}$ & 2.34 & 95 & - \\
\hline (Discharge Water Pumping) & 125 & $\mathrm{MJ} / \mathrm{d}$ & 2.34 & 294 & - \\
\hline \multicolumn{6}{|l|}{ Separations } \\
\hline (Drying Heat) & 9,126 & $\mathrm{MJ} / \mathrm{d}$ & 1.18 & 10,732 & - \\
\hline (Electricity) & 101 & $\mathrm{MJ} / \mathrm{d}$ & 2.34 & 237 & - \\
\hline
\end{tabular}




\begin{tabular}{|l|c|c|c|c|c|}
\hline (Process Heat) & 1,095 & $\mathrm{MJ} / \mathrm{d}$ & 1.18 & 1,288 & - \\
\hline (Hexane) & 2 & $\mathrm{~kg} / \mathrm{d}$ & 16.38 & 25 & 25 \\
\hline Biocrude & 292 & $\mathrm{~kg} / \mathrm{d}$ & 54.49 & 15,919 & 15,919 \\
\hline Algae Meal & 976 & $\mathrm{~kg} / \mathrm{d}$ & 25.08 & 24,478 & 24,478 \\
\hline & & & & & \\
\hline Net System Excesses & & & & & \\
\hline Carbon Dioxide & 19 & $\mathrm{~kg} / \mathrm{d}$ & 0.00 & 0 & 0 \\
\hline Ammonia & 0 & $\mathrm{~kg} / \mathrm{d}$ & 38.72 & 0 & 0 \\
\hline Net Electricity Yield & 24,501 & $\mathrm{MJ} / \mathrm{d}$ & 2.34 & 57,358 & $57,358^{1}$ \\
\hline Net Heat Yield & 17,834 & $\mathrm{MJ} / \mathrm{d}$ & 0.00 & 0 & 0 \\
\hline
\end{tabular}

Table 3. Results for Cases I-IV. ${ }^{1}$ The algae meal is $52 \%$ protein.

\begin{tabular}{|c|c|c|c|c|}
\hline & Case I & Case II & Case III & Case IV \\
\hline Biocrude Yield (kg/d) & 292 & 292 & 292 & 292 \\
\hline Algae Meal Yield (kg/d) & 976 & 976 & 976 & 976 \\
\hline Electricity Yield (MJ/d) & 24,501 & 24,501 & 24,501 & 24,501 \\
\hline Excess Electricity Use & Grid & None & Grid & None \\
\hline Flare Gas Energy Penalty (MJ/kg) & 0 & 0 & 55 & 55 \\
\hline Flare Gas Emissions $\left(\mathrm{kgCO}_{2 \text {-eq }} / \mathrm{kg}\right)$ & 0 & 0 & 2.7 & 2.7 \\
\hline Energy Input (MJ/d) & 614 & 614 & 83,309 & 83,309 \\
\hline Energy Output (MJ/d) & 97,755 & 40,397 & 97,755 & 40,397 \\
\hline Emissions $\left(\mathrm{kgCO}_{2 \text {-eq }} / \mathrm{d}\right)$ & 3 & 3 & 4,138 & 4,138 \\
\hline Displacement Credits $\left(\mathrm{kgCO}_{2 \text {-eq }} / \mathrm{d}\right)$ & $-6,720$ & $-1,952$ & $-6,720$ & $-1,952$ \\
\hline Biogenic Credits $\left(\mathrm{kgCO}_{2 \text {-eq }} / \mathrm{d}\right)$ & $-2,933$ & $-2,933$ & $-2,933$ & $-2,933$ \\
\hline EROI & 159.2 & 65.8 & 1.2 & 0.5 \\
\hline Energy Impact Algae Meal (MJ/kg) & 0.23 & 0.40 & 31.0 & 53.9 \\
\hline Energy Impact Protein ${ }^{1}$ (MJ/kg protein) & 0.44 & 0.76 & 59.1 & 102.7 \\
\hline Greenhouse Gas Emissions (gCO $\mathrm{gCe}_{2 \text {-eq }} / \mathrm{MJ}$ ) & -786 & -398 & -450 & -61 \\
\hline
\end{tabular}

\subsection{Energy Return on Investment}

The EROI for Case I is the highest EROI ever reported for an algal energy production system $[8,59]$ due to the convenient use of flare gas to power the system and the discounted value of the gas because of its status as a waste stream. The large return on investment highlights the potential benefit to society that this system could provide. For 
instance, as shown in Figure 2, the EROI for Case I exceeds that for all fossil fuels and all conventional crop production systems.

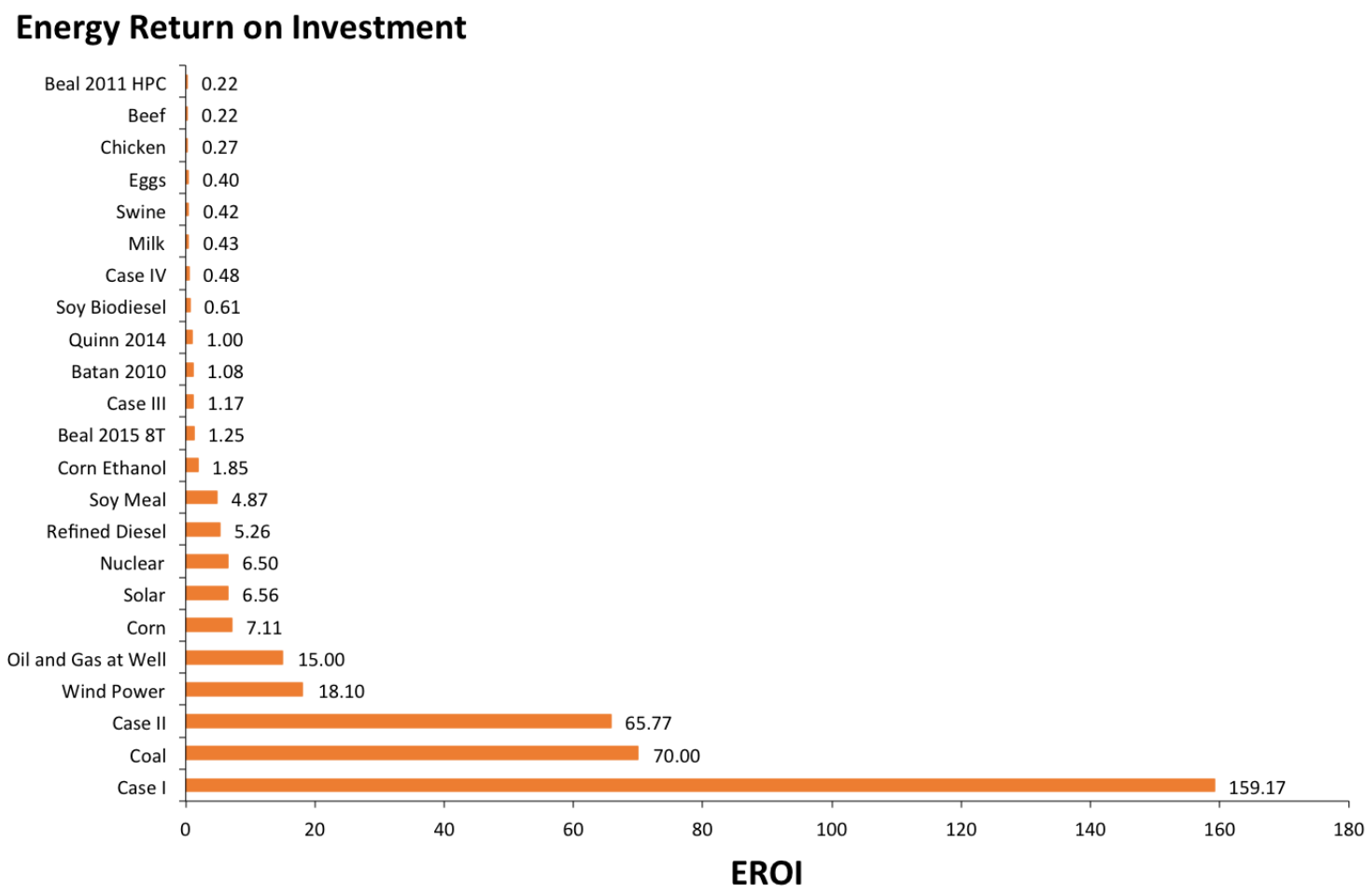

Figure 2. EROI for various fuels and crops including results from this study. Data are from: Beal et al. [9], Quinn et al. [15], De Vries and De Boer [23], Beal et al. [26], Batan et al. [43], Argonne National Laboratory [51], Carlsson-Kanyama et al. [60], Pelletier [61], United States Department of Agriculture [62], Shapouri et al. [63], Field and Taylor [64], Gupta and Hall [65], Kubiszewski et al. [66], Cleveland [67], Kubiszewski et al. [68], King [69], Cleveland [70]

The large return on investment of Case I is afforded due to the investment that was undertaken during oil-and-gas production that generated the flare gas; namely, the investments of energy and capital count as inputs to the oil-and-gas system rather than the algal production system. Widespread deployment of the proposed algae systems would likely require reconsidering the system boundaries to include the entire oil-and-gas operation in addition to the algae production system, thereby generating an overall EROI for the integrated oil-and-gas-and-algae facility. For instance, the energy and emissions 
associated with establishing the oil-and-gas facilities would then be allocated among all process outputs, including algae. Such an integrated EROI is expected to be lower, though still relatively high.

Removing the electricity co-product from the system (Case II), which might apply if the algae facility could not be connected to the grid, reduces the EROI significantly. However, the EROI for Case II is still higher than any other algae production models [8, 59]. When the energy impact of flare gas is implemented (Case III) the EROI is reduced considerably near unity. Lastly, if the electricity co-product is removed and the energy value of the flare gas is included, representing the most conservative evaluation, (Case IV) the EROI further is decreased below unity. These latter scenarios are comparable to typical algal biofuel analyses that incur negative impacts associated with market electricity and heat consumption. As expected, the large heat requirements for drying the algal biomass are detrimental to the EROI. For Case IV, where the chemical energy in flare gas is counted and electricity is excluded as a co-product, the EROI drops below unity, indicating that more energy is consumed by the system than produced. The accounting of flare gas for these systems is challenging, as the current mode of operation is flaring the gas, rendering the gas as a zero-value waste product. The sensitivity of model results through the various scenarios illustrates the importance of understanding the inputs and products for the system.

\subsection{Energy Impact of Protein-Rich Animal Feed}

The energy required to produce a variety of food products has been reported by numerous researchers and the results for Case I and Case II from this study are among the lowest 
energy inputs of any products reported, including fruits, vegetables, cereals, meat, and dairy products, some of which are compared in Figure 3 [23, 60, 61, 71-73]. As for the promising EROI results for these cases, the low energy impact results can be attributed to omitting the energy content of flare gas from the system accounting for these cases. This accounting standard is consistent for how waste streams are treated in lifecycle analysis. Still, these results demonstrate that the proposed system in this study could produce food products in an energetically favorable way utilizing a waste stream, low quality land, and saline water.

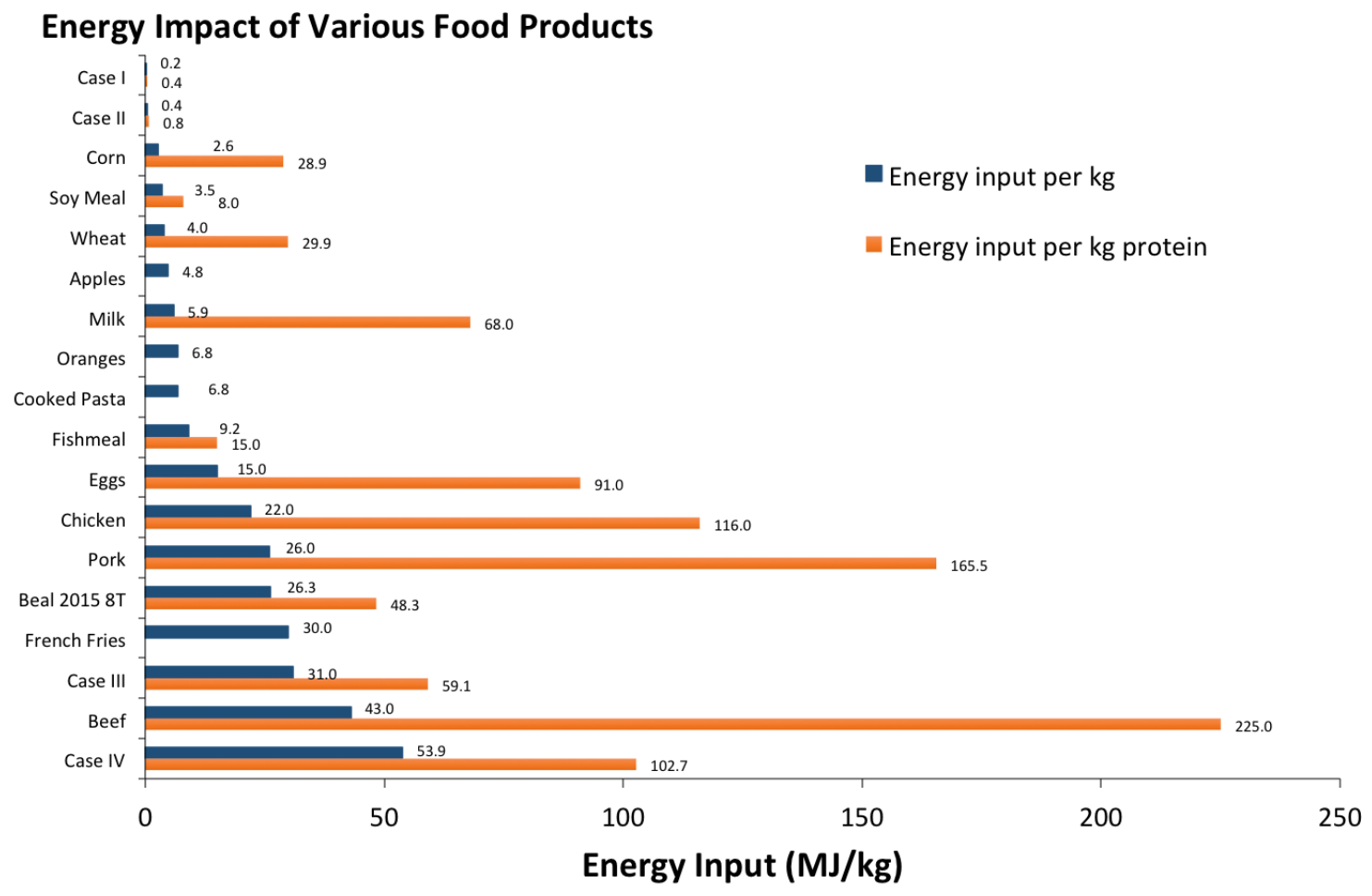

Figure 3. Energy impact of various food products per $\mathrm{kg}$ and per $\mathrm{kg}$ of protein. (Impact per $\mathrm{kg}$ protein not shown for products with very low protein content.) Data is sourced from: Beal et al. [9], De Vries and De Boer [23], Carlsson-Kanyama et al. [60], Pelletier [61], Field and Taylor [64], Frorip et al. [72], Williams et al. [73] 
The results of this study are favorable when compared to previous studies. Using data from the recent study by Beal et al. [9], the energy impact of algae meal produced in that system can be estimated to be $26 \mathrm{MJ} / \mathrm{kg}$ (Case $8 \mathrm{~T}$ ), which is roughly 10 times that of corn, 7 times that of soy, and 3 times that of fishmeal [61]. The energy inputs in the system described by Beal et al. [9] are mostly associated with water supply and circulation energy (the carbon source for that study was $94 \%$ pure and nearby, thus reducing carbon-related inputs). Meanwhile, utilizing waste flare gas enables algae meal production for Case I $(0.2 \mathrm{MJ} / \mathrm{kg})$ and Case II $(0.4 \mathrm{MJ} / \mathrm{kg})$ at fractions of the energy required for corn, soy, and fishmeal, which are directly comparable animal feed ingredients $[55,56,58,74]$. The protein quality of algae meal is comparable to soymeal, with potential advantages associated with desirable omega-3 fatty acids. Furthermore, the algae meal produced in Case I ( $0.4 \mathrm{MJ} / \mathrm{kg}$ protein) and Case II $(0.8 \mathrm{MJ} / \mathrm{kg}$ protein) greatly outperforms other protein sources such as soy meal ( $8 \mathrm{MJ} / \mathrm{kg}$ protein), milk (91 $\mathrm{MJ} / \mathrm{kg}$ protein), eggs ( $97 \mathrm{MJ} / \mathrm{kg}$ protein), and meats, including beef (225 MJ/kg protein) $[23,72]$.

However, when the energy content of the flare gas used to power the system is included, the energy impact of algae meal increases for Cases III and IV to 31 and 54, respectively, and no longer is competitive with corn, soy, and fishmeal. As expected, the results are also worse than the algae meal reported by Beal et al. [9] (Case 8T) that did not require complete algae drying. Cases III and IV compare more closely with the energy impact of meat production (pork, chicken, and beef) than that of crops.

Protein has the potential to be a limited resource due to global population increase and the finite agricultural land available for traditional protein production. The proposed 
process represents an alternative production pathway that does not directly compete for valuable agricultural land or fresh water. The promising EROI for protein production is achieved through the direct integration with an energy dense waste stream from the oil and gas industry. The proposed process has the potential to be an alternative production pathway for protein with economic assessment required to critically assess the commercial viability.

\subsection{Environmental Impact}

The environmental impact of the system was evaluated for the various cases with results presented in Table 3 and Figure 4. In all of the scenarios, the environmental impact of the system benefits from microalgae utilizing waste carbon dioxide. Case I represents the most environmentally favorable scenario as expected. The results from this scenario are an order of magnitude more beneficial than the most beneficial value reported in literature for algal biofuel production [8]. The favorable results are due to receiving flare gas as a waste product and allocating the associated emissions to the oil and gas industry. The flare gas, if not utilized by the proposed system, is burned and released to the atmosphere. The system utilizes the flare gas to generate valuable products that are not only used in the microalgae biorefinery but exported as co-products. Specifically electricity and protein rich animal feed represent environmentally impactful co-products. The excess electricity that was produced without carbon emissions in Case I displaces grid electricity resulting in a significant environmental credit. Results for Case II illustrate the impact of eliminating the excess electricity as a co-product. However, the environmental impact is still a factor of four better than any other study. Case III 
assumes the methane fuel is not a waste product (and is therefore treated as procured natural gas rather than flare gas) and emissions associated with carbon contained in the natural gas are integrated in the analysis. The promising environmental impact for Case III is dominated by the co-product credit associated with excess electricity production. Results from Case IV represent purchasing methane for the system (rather than assuming a waste product in flare gas) and exclude the excess electrical energy exports. The vast differences in results for Cases I-IV indicate the sensitivity of life-cycle assessments to the associated accounting methods for repurposing a waste stream.

Co-product displacement emissions dramatically impact the results from this study. The displacement method represents the standard allocation method for biofuel systems [24]. Alternatively, an energy allocation method was also evaluated for all cases resulting in the following net $\mathrm{CO}_{2}$ eq emissions for Cases I-IV, respectively: -51, -88, 21, and $36 \mathrm{~g}$ $\mathrm{CO}_{2} \mathrm{eq} / \mathrm{MJ}$. For this accounting method, the net emissions from the facility (total emissions less net biogenic carbon uptake into the biomass) are allocated based on the energy content of the products included in each case: biocrude, animal feed, and when applicable, electricity. The different accounting methods generated notably different results, once again indicating the importance of accounting assumptions in life-cycle assessment. Environmental impact results, independent of allocation method, for the integration of flare gas with algae cultivation illustrate a synergistic relationship. 


\section{GHG Emissions (g CO$\left.{ }_{2} \mathrm{eq} / \mathrm{MJ}\right)$}

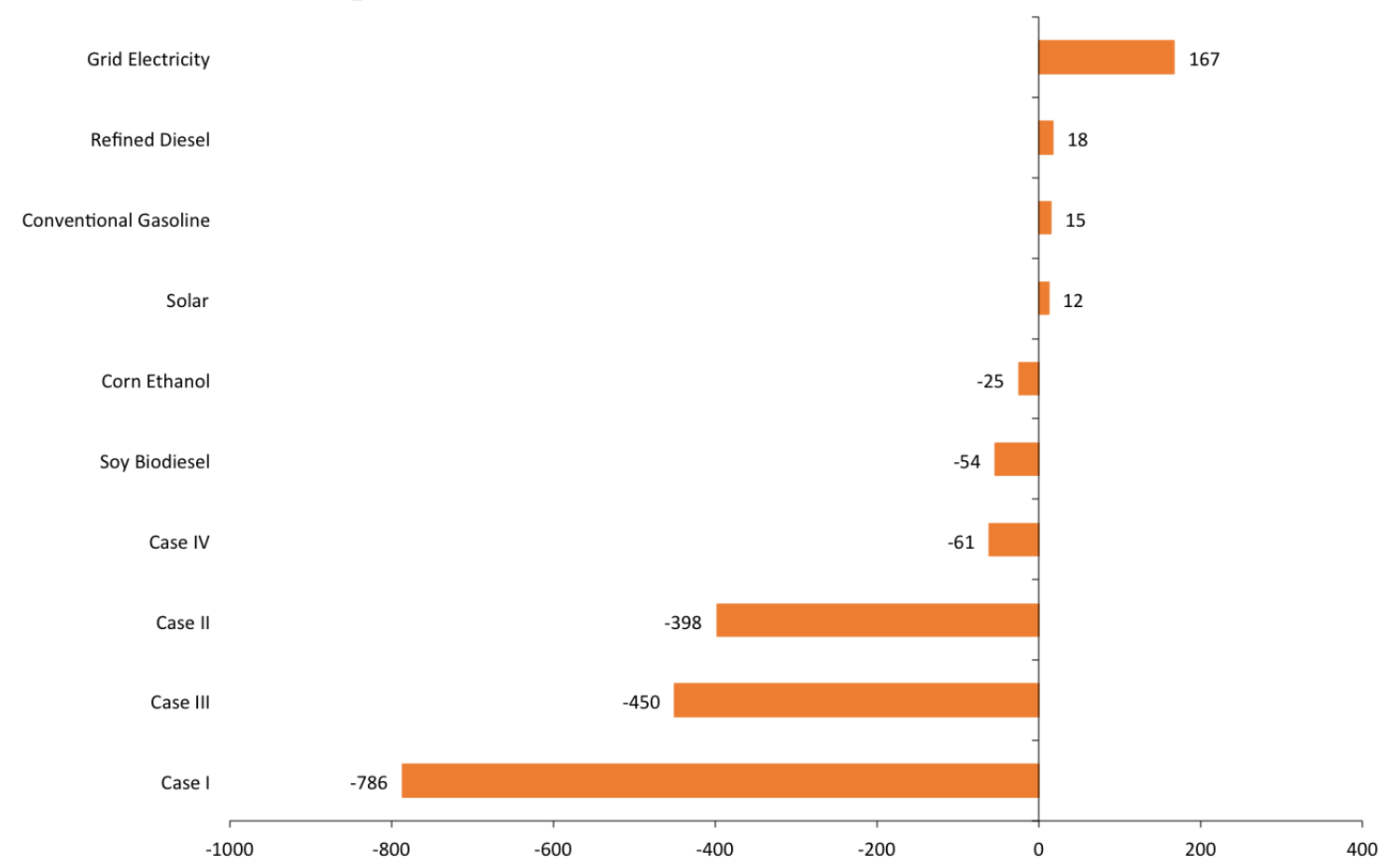

Figure 4. GHG impact of various fuels per MJ of energy output based on the displacement accounting method [51].

\subsection{Sensitivity Analysis}

Sensitivity analysis was used to understand model inputs that dramatically impact results. Figure 5 presents the sensitivity analyses for the EROI, energy impact of algae meal, and greenhouse gas emissions for Cases I and III. All parameters evaluated with sensitivity and shown in Figure 5 were varied by $+/-20 \%$ with respect to the baseline values listed in Table 1 unless otherwise noted. The largest impact to the EROI is associated with variations in the assumed HHV for flare gas (Case III only), followed by assigning a nonrenewable energy impact to the algae meal displacement credit $(3.5 \mathrm{MJ} / \mathrm{kg}$, rather than 
the total energy impact of $25 \mathrm{MJ} / \mathrm{kg}$ [9]), which reduced the EROI for Cases I and III by over $20 \%$ each. As expected, both cases are strongly dependent on the HHV of flare gas and the electricity generation efficiency, indicating the importance of selling excess electricity in these cases (see Cases II and IV for comparison with results without credit for excess electricity). Surprisingly, an increase in the biomass productivity negatively impacts results for Case I due to increased DAP consumption (which is $95 \%$ of the energy input at the system boundary). Conversely, a 20\% increase in productivity triggers over 5\% improvement of the EROI for Case III because the energy inputs are dominated by the flare gas energy content and increased yield increases meal and biocrude production, which directly impact the functional units of the system. Due to the dependence of Case I on DAP consumption, the nutrient uptake efficiency also has a large impact, where reducing the phosphorus uptake efficiency to $75 \%$ results in over $15 \%$ reduction of EROI and a nearly $20 \%$ adverse impact in the algae meal energy impact. Sensitivity results for the GHG emissions are highly dependent on the oil yield (i.e., the denominator of $\mathrm{g} \mathrm{CO}_{2} \mathrm{eq} / \mathrm{MJ}$ ) and the allocation of emissions to end products, as large displacements for LEA and electricity skew results in a non-intuitive direction. The model shows relatively little sensitivity to the other algae production parameters and zero sensitivity to $20 \%$ variations in heat recovery efficiency due to the large excess in heat produced by CHP. 


\section{Percent Change in EROI for Cases I and III}

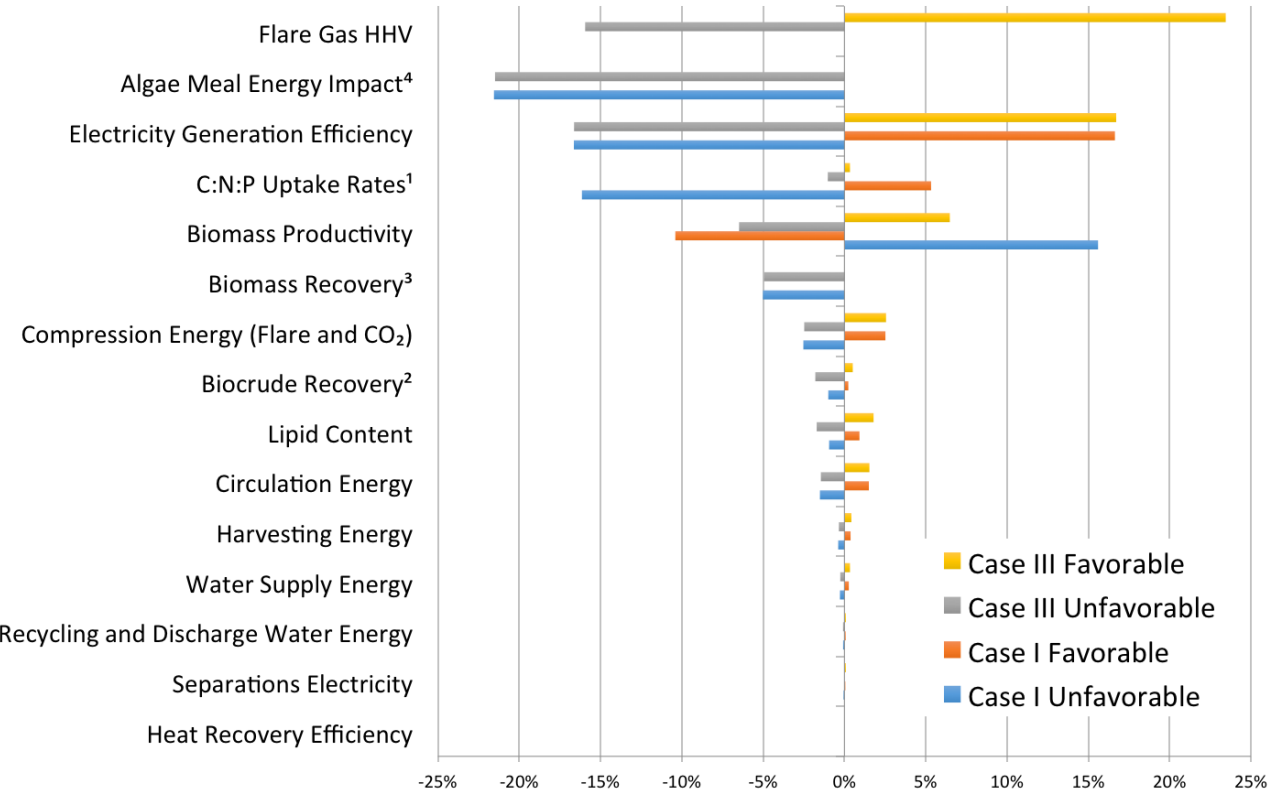

\section{Percent Change in Algae Meal Energy Impact for Cases I and III}

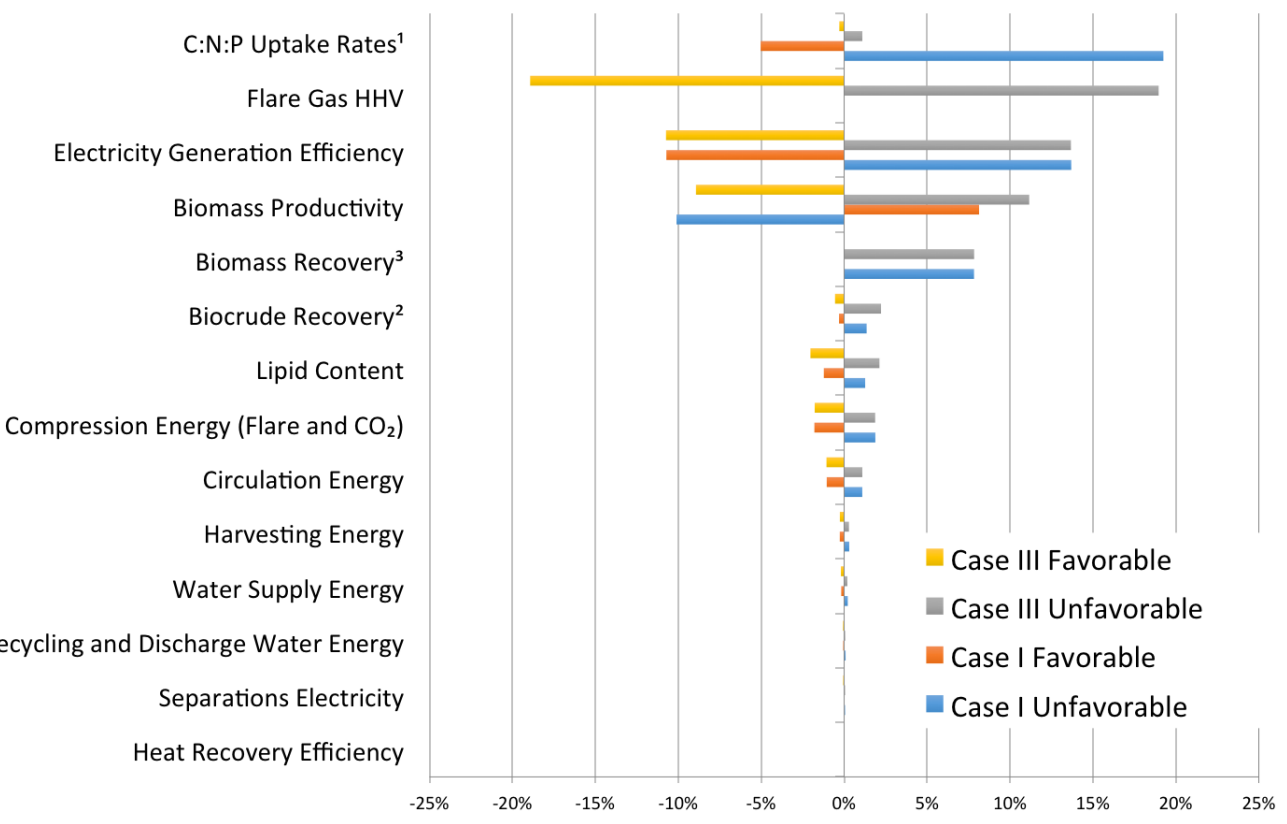


Percent Change in Net CO2e Emissions for Cases I and III

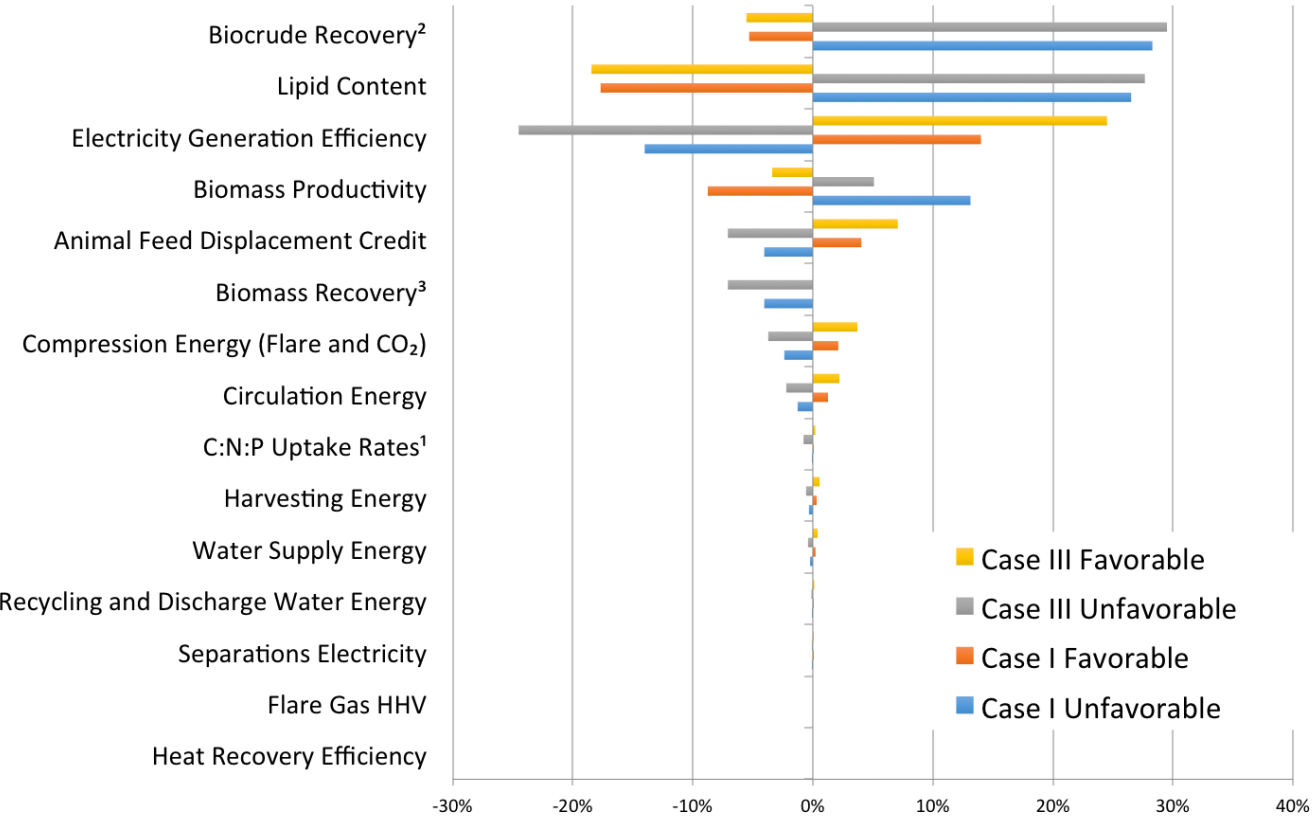

Figure 5. Sensitivity analysis results for the EROI, algae meal energy impact, and greenhouse gas emissions. Results are shown as percent change. All parameters were varied by $+/-20 \%$ except where noted. ${ }^{1}$ Favorable $C: N: P$ uptake rates are $0.9: 0.95: 0.95$, while unfavorable rates are 0.5:0.75:0.75. ${ }^{2}$ Favorable biocrude recovery is $100 \%$; unfavorable is $75 \%$. ${ }^{3}$ Baseline LEA biomass recovery efficiency is $100 \%$ so there is no favorable value; unfavorable value is $80 \%{ }^{4}$ Total $(25.08$ $\mathrm{MJ} / \mathrm{kg}$ ) and non-renewable (3.5 MJ/kg) energy impacts.

\section{DISCUSSION AND CONCLUSION}

\subsection{Production Potential}

The scalability of the proposed systems is directly coupled to flare gas production. The proposed system produces roughly $300 \mathrm{~kg} / \mathrm{d}$ of biocrude and $1,000 \mathrm{~kg} / \mathrm{d}$ of algae meal when integrated with a flare gas recovery system yielding roughly $2,000 \mathrm{~m}^{3} /$ day of natural gas equivalent fuel. If all of the flare gas in the United States were used in the proposed system, 8.8 million bbl of biocrude and 3.6 million metric tonnes of dry protein-rich meal could be produced annually, equating to $29 \%$ of domestic biodiesel production and $14 \%$ of the U.S. soybean meal market $[75,76]$. For a global perspective, 
if all of the flare gas in the world were used in the proposed system, 126 million bbl of biocrude and 57 million metric tonnes of algal protein meal could be produced annually. At the same time, this approach would dramatically reduce flaring. Geographic siting represents a critical component to the feasibility of the proposed process. As of 2014, a large fraction (about 45\%) of the flared and vented gas in the US was in North Dakota [17] where the climate would decrease the productivity of the system, even needing to be shut down during winter months. Approximately $34 \%$ of all flare gas is in Texas and the gulf coast region, which represents a more optimal location for algal growth. As previously discussed, the site could also be located abroad where flaring is much more prevalent. Countries such as Nigeria and Venezuela have favorable climates for growing algae and large quantities of unused flare gas.

\subsection{Additional Benefits of Algae Meal Production}

In addition to the promising energetics associated with using flare gas to produce algae, algae meal production provides several resource benefits including low land-intensity, limited fresh water impacts, improved nutrient use as compared to terrestrial crops, and value-added protein meal containing omega-3 fatty acids. The land intensity of the algae meal in this model is $0.3 \mathrm{~m}^{2}$ per year per $\mathrm{kg}$ of meal produced, which is order(s) of magnitude less than milk $\left(1.5 \mathrm{~m}^{2} / \mathrm{kg}\right.$-yr $)$, eggs $\left(5.5 \mathrm{~m}^{2} / \mathrm{kg}\right.$-yr $)$, pork $\left(\sim 10 \mathrm{~m}^{2} / \mathrm{kg}-\mathrm{yr}\right)$, chicken ( $\sim 9 \mathrm{~m}^{2} / \mathrm{kg}$-yr), and beef ( $\sim 38 \mathrm{~m}^{2} / \mathrm{kg}$-yr) [23]. By using saline water to grow the algae, the only direct consumption of fresh water in the proposed system is for ammonia production $(0.19 \mathrm{~L} / \mathrm{kg}$ algae meal); the freshwater consumption represents massive fresh water reductions compared to corn $(246 \mathrm{~L} / \mathrm{kg})$ and soy $(42 \mathrm{~L} / \mathrm{kg})$ production [9]. 
Upstream and embedded water impacts (which were not calculated explicitly) are minimized by onsite CHP with recycled cooling water for heat recovery. Water impacts could be minimized further by treating and recycling produced water from oil and gas operations that could then be used in algae ponds. Nutrient use was modeled at $90 \%$ for this study although elemental balances near 100\% have been measured at pilot scale [77]. Uptake rates of $90-100 \%$ are significant improvements compared to terrestrial crops [78, 79] and could contribute to reduced eutrophication. Finally, the added benefits of algae meal composition include high protein content $(\sim 50 \%)$ and inclusion of valuable omega3 fatty acids that could improve livestock health and be passed through to human consumers.

\subsection{Alternative Scenarios}

Alternative scenarios for flare gas utilization were considered. For instance, rather than using the flare gas to power an integrated algae facility, the energy-dense fuel could be used to produce electricity delivered to regional grids. The EROI for the CHP facility modeled in this study would be 232 omitting the energy content of flare gas (thereby

outperforming Case I) or 1.03 when including flare gas energy (underperforming Case III due to the large animal feed displacement credit). Constructing natural gas pipelines to connect reserves with population centers has been proposed [80], although the overall energy impact of adapting this policy to flare gas (thus requiring energy to construct pipelines and transport the gas) is not explicitly known. Alternatively, the excess gas could be used to power energy-intensive processes such as aluminum production [81], desalination plants [82], internet data centers [83], or ammonia fertilizer production 
independent of an algal cultivation system $[84,85]$. Biological fermentation processes also exist for converting gaseous streams such as flare gas into lipids useful for fuel production [86]. The scenario could be modified to focus on biofuel production from algae with the integration of a thermochemical conversion route that can recycle nutrients ( $\sim 50-90 \%$ recycling), although this approach would destroy the valuable protein fraction [49]. Each of these scenarios has challenges associated with raw material and end product transportation. Further, the discussed processes do not provide products that are expected to be in limited supply such as protein, and thus the integration of algal production with flare gas represents a unique synergistic activity.

The proposed concept of using flare gas to power an algal production facility could be extended to include other sources of waste energy. For instance, until recent improvements in transmission capacity, significant amounts of electricity from wind turbines in west Texas had to be curtailed. Similar underutilized energy resources could be repurposed to power facilities that grow algae for protein and bio-fuels. Repurposing the underutilized energy resources for productive means can thus be used as a proxy for large-scale energy storage.

\subsection{Logistics}

The flow rate and composition of flare gas at oil and gas well sites can vary significantly over time. The composition of the flare gas often varies from well-to-well and also over the course of a well's lifetime. As oil-and-gas production rates drop off over the lifetime of the well it can be expected that the flow rate of flare gas will also decline. During the first few days of operation a hydraulically fractured oil well might produce associated gas 
volumes of over $28,000 \mathrm{~m}^{3} /$ day $(1,000,000 \mathrm{mmscfd})$, all of which is flared. The flow rate of flare gas might decrease to less than $280 \mathrm{~m}^{3} /$ day $(10,000 \mathrm{scfd})$ by the end of the first year. A conventional oil well might operate productively for 10 years or more, but unconventional shale oil wells might only last 3-5 years [87]. The declining production rates and subsequent decrease in flow rates of flare gas present a challenge for the proposed algal production facility if it sources flare gas from unconventional wells. To achieve economic viability a location needs ample supply of excess flare gas for the foreseeable future (20-30 year facility lifetime $[8,9])$. Such assurance might be accomplished by aggregating the supply of flare gas from multiple adjacent production sites or to store excess flare gas for use during a flare gas shortage. Flare sources within a reasonable distance from the existing algae production facility could be transported to the facility by pipeline. Or, the algae facility could be located near a more dependable supply of flare gas, such as large refineries and production sites abroad that consistently flare significant quantities of natural gas [16].

Alternatively, the algae production facility could be designed to enable relocation after a flare source is exhausted prematurely. The oil-and-gas industry re-locates equipment routinely, including massive onshore and offshore drilling rigs that are much more complex than the system proposed here. If a source of flare gas is terminated, the algae production and processing facilities could be re-located and re-used. If re-location is anticipated, the pond liners could be installed in pieces, above ground piping could be used, and portable buildings could be installed. Other mechanical equipment (paddlewheels, CHP, processing equipment, etc.) could also be re-located. Transporting 
gas from a remote flare gas source or relocating the facility would incur a large additional cost that needs further consideration during a complete techno-economic analysis.

\subsection{Future Work}

Future work will consider the economic constraints for constructing and operating the proposed algae growth facility. The modeled system includes the production of a valuable co-product, protein feed, as it is expected that this co-product is required to improve the economic viability of an algae-based biofuel facility. A more detailed consideration of the logistical challenges associated with producing a steady source of biomass from a variable source of flare gas will also be considered, including the impact of utilizing natural gas storage. In order to accomplish this, further analysis will be completed to identify promising domestic and international sites for the proposed concept. Lastly, the potential economic cost associated with re-locating the algae production facility if a flare gas source is closed will be determined.

\section{ACKNOWLEDGEMENTS}

This work was partially supported by the U.S. Department of Energy (DE-EP0000011), the Alfred P. Sloan Foundation, and the Cynthia and George Mitchell Foundation. We thank Jeffrey Phillips for assistance with the manuscript.

\section{REFERENCES}


[1] J.W. Erisman, M.A. Sutton, J. Galloway, Z. Klimont, W. Winiwarter. How a century of ammonia synthesis changed the world. Nature Geoscience 1 (2008) 636-9.

[2] D. Tilman, C. Balzer, J. Hill, B.L. Befort. Global food demand and the sustainable intensification of agriculture. Proceedings of the National Academy of Sciences 108 (2011) 20260-4.

[3] H. Aiking. Future protein supply. Trends in Food Science \& Technology 22 (2011) $112-20$.

[4] V. Smil. The earth's biosphere: Evolution, dynamics, and change, MIT Press, 2003.

[5] J.H. Ryther. Potential productivity of the sea organic production by marine plankton algae is comparable to agricultural yields on land. Science 130 (1959) 602-8.

[6] W. Cramer, D. Kicklighter, A. Bondeau, B. Moore III, G. Churkina, B. Nemry, et al. Comparing global models of terrestrial net primary productivity (NPP): Overview and key results. Global change biology 5 (1999) 1-15.

[7] Department of Energy. Bioenergy technologies office's past solicitations and awardees. January 2016) http://www.energy.gov/eere/bioenergy/pastsolicitations\#Advanced_Biofuels_Technology_Development_and_Sustainable_Bioenerg y_Feedstock_Productio,DOERoadmap

[8] J.C. Quinn, R. Davis. The potentials and challenges of algae based biofuels: A review of the techno-economic, life cycle, and resource assessment modeling. Bioresource technology 184 (2015) 444-52.

[9] C.M. Beal, L.N. Gerber, D.L. Sills, M.E. Huntley, S.C. Machesky, M.J. Walsh, et al. Algal biofuel production for fuels and feed in a 100-ha facility: A comprehensive technoeconomic analysis and life cycle assessment. Algal Research 10 (2015) 266-79. [10] E.P. Bennion, D.M. Ginosar, J. Moses, F. Agblevor, J.C. Quinn. Lifecycle assessment of microalgae to biofuel: Comparison of thermochemical processing pathways. Applied Energy 154 (2015) 1062-71.

[11] R. Davis, C. Kinchin, J. Markham, E.C.D. Tan, L.M.L. Laurens. Process design and economics for the conversion of algal biomass to biofuels: Algal biomass fractionation to lipid- and carbohydrate-derived fuel products. U.S. Department of Energy Bioenergy Technologies Office2014.

[12] R.E. Davis, D.B. Fishman, E.D. Frank, M.C. Johnson, S.B. Jones, C.M. Kinchin, et al. Integrated evaluation of cost, emissions, and resource potential for algal biofuels at the national scale. Environ Sci Technol 48 (2014) 6035-42.

[13] E.D. Frank, J. Han, I. Palou-Rivera, A. Elgowainy, M.Q. Wang. Life-cycle analysis of algal lipid fuels with the greet model. Center for Transportation Research, Energy Systems Division, Argonne National Laboratory, Oak Ridge, TN, 2011. [14] T.J. Lundquist, I.C. Woertz, N.W.T. Quinn, J.R. Benemann. A realistic technology and engineering assessment of algae biofuel production. Energy Biosciences Institute, Berkeley, CA, 2010.

[15] J.C. Quinn, T.G. Smith, C.M. Downes, C. Quinn. Microalgae to biofuels lifecycle assessment-multiple pathway evaluation. Algal Research 4 (2014) 116-22.

[16] C.D. Elvidge, M. Zhizhin, K. Baugh, F.-C. Hsu, T. Ghosh. Methods for global survey of natural gas flaring from visible infrared imaging radiometer suite data. Energies 9 (2015) 14. 
[17] U.S. Energy Information Administration. Natural gas gross withdrawals and production. January 2016)

http://www.eia.gov/dnav/ng/ng_prod_sum_a_epg0_vgv_mmcf_a.htm

[18] U.S. Energy Information Administration. State profile and energy estimates, texas, texas net electricity generation by source. January 2016)

http://www.eia.gov/state/?sid=TX\#tabs-4

[19] Environmental Protection Agency. Understanding global warming potentials. January 2015) http://www3.epa.gov/climatechange/ghgemissions/gwps.html

[20] R. Salmon, A. Logan. Flaring up: North dakota natural gas flaring more than doubles in two years. Ceres (2013).

[21] C.D. Elvidge, D. Ziskin, K.E. Baugh, B.T. Tuttle, T. Ghosh, D.W. Pack, et al. A fifteen year record of global natural gas flaring derived from satellite data. Energies 2 (2009) 595-622.

[22] K. Mulder, N.J. Hagens. Energy return on investment: Toward a consistent framework. AMBIO: A Journal of the Human Environment 37 (2008) 74-9.

[23] M. De Vries, I. De Boer. Comparing environmental impacts for livestock products: A review of life cycle assessments. Livestock science 128 (2010) 1-11.

[24] M. Wang, H. Huo, S. Arora. Methods of dealing with co-products of biofuels in lifecycle analysis and consequent results within the US context. Energy Policy 39 (2011) 5726-36.

[25] J.C. Quinn, K.B. Catton, S. Johnson, H.B. Thomas. Geographical assessment of microalgae biofuels potential incorporating resource availability. BioEnergy Research 6 (2012) 591-600.

[26] C.M. Beal, A.S. Stillwell, C.W. King, S.M. Cohen, H. Berberoglu, R.P. Bhattarai, et al. Energy return on investment for algal biofuel production coupled with wastewater treatment. Water Environment Research 84 (2012) 692-710.

[27] U.S. EPA Office of Air Quality Planning and Standards. State profile and energy estimates, oregon, oregon electricity profile January 2016)

http://www.eia.gov/electricity/state/Oregon/

[28] L. Gilmer, C. Caico, J. Sherrick, G. Mueller, K. Loos. Flare waste gas flow rate and composition measurement methodologies evaluation document. In: Shell GLobal

Solutions, (Ed.)2004.

[29] P.J. Linstrom, W. Mallard. NIST chemistry webbook; NIST standard reference database no. 69. (2001).

[30] M.J. Moran, H.N. Shapiro, D.D. Boettner, M.B. Bailey. Fundamentals of engineering thermodynamics, John Wiley \& Sons, 2010.

[31] GE Corperation. Jenbacher type 6 engine specification sheet. 2015.

[32] K. Darrow, R. Tidball, J. Wang, A. Hampson. Catalog of chp technologies. ICF Int, funding: US Environmental Protection Agency, Combined Heat and Power Partnership, US Dept of Energy (2015).

[33] R. Pavri, G.D. Moore. Gas turbine emissions and control. General Electric Report No GER-4211 (2001).

[34] E. Worrell, D. Phylipsen, D. Einstein, N. Martin. Energy use and energy intensity of the US chemical industry. Lawrence Berkeley National Laboratory (2000). 
[35] C. Jiménez-González, S. Kim, M.R. Overcash. Methodology for developing gate-togate life cycle inventory information. The International Journal of Life Cycle Assessment 5 (2000) 153-9.

[36] R. Davis, J. Markham, C. Kinchin, N. Grundl, E.C.D. Tan. Process design and economics for the production of algal biomass: Algal biomass production in open pond systems and processing through dewatering for downstream conversion. U.S. Department of Energy,2016.

[37] A.C. Redfield. The biological control of chemical factors in the environment. American Scientist 46 (1958) 205-21.

[38] M.E. Huntley, Z.I. Johnson, S.L. Brown, D.L. Sills, L. Gerber, I. Archibald, et al. Demonstrated large-scale production of marine microalgae for fuels and feed. Algal Research 10 (2015) 249-65.

[39] C.M. Beal, C.H. Smith, M.E. Webber, R.S. Ruoff, R.E. Hebner. A framework to report the production of renewable diesel from algae. BioEnergy Research 4 (2011) 3660.

[40] J. Quinn, L. de Winter, T. Bradley. Microalgae bulk growth model with application to industrial scale systems. Bioresource Technology 102 (2011) 5083-92.

[41] J.C. Quinn, C.W. Turner, T.H. Bradley. Scale-up of flat plate photobioreactor considering diffuse and direct light characteristics. Biotechnology and Bioengineering 109 (2011) 363-70.

[42] J.C. Quinn, T. Yates, N. Douglas, K. Weyer, J. Butler, T.H. Bradley, et al. Nannochloropsis production metrics in a scalable outdoor photobioreactor for commercial applications. Bioresource Technology 117 (2012) 164-71.

[43] L. Batan, J. Quinn, B. Willson, T. Bradley. Net energy and greenhouse gas emission evaluation of biodiesel derived from microalgae. Environ Sci Technol 44 (2010) 797580.

[44] C.M. Beal, R.E. Hebner, M.E. Webber, R.S. Ruoff, A.F. Seibert. The energy return on investment for algal biocrude: Results for a research production facility. BioEnergy Research 5 (2012) 341-62.

[45] R. Davis, J. Markham, C. Kinchin, N. Grundl, E.C. Tan, D. Humbird. Process design and economics for the production of algal biomass: Algal biomass production in open pond. (2016).

[46] B. Ketheesan, N. Nirmalakhandan. Development of a new airlift-driven raceway reactor for algal cultivation. Applied Energy 88 (2011) 3370-6.

[47] J.W. Moody, C.M. McGinty, J.C. Quinn. Global evaluation of biofuel potential from microalgae. Proceedings of the National Academy of Sciences (2014).

[48] M.S. Wigmosta, A.M. Coleman, R.J. Skaggs, M.H. Huesemann, L.J. Lane. National microalgae biofuel production potential and resource demand. Water Resour Res 47 (2011).

[49] S. Jones, R. Davis, Y. Zhu, C. Kinchin, D. Anderson, R. Hallen, et al. Process design and economics for the conversion of algal biomass to hydrocarbons: Whole algae hydrothermal liquefaction and upgrading. U.S. Department of Energy Bioenergy Technologies Office2014.

[50] L. Lardon, A. Helias, B. Sialve, J.P. Stayer, O. Bernard. Life-cycle assessment of biodiesel production from microalgae. Environmental Science \& Technology 43 (2009) 6475-81. 
[51] Argonne National Laboratory. Greet 2015 model. 2015.

[52] K.M. Weyer, D.R. Bush, A. Darzins, B.D. Willson. Theoretical maximum algal oil production. BioEnergy Research 3 (2009) 204-13.

[53] National Renewable Energy Laboratory. U.S. Life cycle inventory database. 2015.

[54] A.D. González, B. Frostell, A. Carlsson-Kanyama. Protein efficiency per unit energy and per unit greenhouse gas emissions: Potential contribution of diet choices to climate change mitigation. Food Policy 36 (2011) 562-70.

[55] S. Gatrell, K. Lum, J. Kim, X.G. Lei. Nonruminant nutrition symposium: Potential of defatted microalgae from the biofuel industry as an ingredient to replace corn and soybean meal in swine and poultry diets. Journal of Animal Science 92 (2014) 1306-14. [56] R. Ekmay, S. Gatrell, K. Lum, J. Kim, X.G. Lei. Nutritional and metabolic impacts of a defatted green marine microalgal (Desmodesmus sp.) biomass in diets for weanling pigs and broiler chickens. Journal of Agricultural and Food Chemistry 62 (2014) 978391.

[57] L.N. Gerber, J.W. Tester, C.M. Beal, M.E. Huntley, D.L. Sills. Target cultivation and financing parameters for sustainable production of fuel and feed from microalgae. Environ Sci Technol 50 (2016) 3333-41.

[58] V. Kiron, M. Sørensen, M. Huntley, G.K. Vasanth, Y. Gong, D. Dahle, et al. Defatted biomass of the microalga, Desmodesmus sp., can replace fishmeal in the feeds for atlantic salmon. Frontiers in Marine Science 3 (2016).

[59] D.L. Sills, V. Paramita, M.J. Franke, M.C. Johnson, T.M. Akabas, C.H. Greene, et al. Quantitative uncertainty analysis of life cycle assessment for algal biofuel production. Environmental Science \& Technology 47 (2013) 687-94.

[60] A. Carlsson-Kanyama, M.P. Ekström, H. Shanahan. Food and life cycle energy inputs: Consequences of diet and ways to increase efficiency. Ecological Economics 44 (2003) 293-307.

[61] N. Pelletier. Environmental performance in the US broiler poultry sector: Life cycle energy use and greenhouse gas, ozone depleting, acidifying and eutrophying emissions. Agricultural Systems 98 (2008) 67-73.

[62] United States Department of Agriculture. National nutrient database for standard reference release 28. January 2016) http://ndb.nal.usda.gov/ndb/foods

[63] H. Shapouri, J.A. Duffield, M.Q. Wang. The energy balance of corn ethanol: An update. United States Department of Agriculture, Economic Research Service2002.

[64] T.G. Field, R.E. Taylor. Scientific farm animal production an introduction to animal science, 10th ed. Boston, Pearson Prentice Hall, 2012.

[65] A.K. Gupta, C.A. Hall. A review of the past and current state of EROI data.

Sustainability 3 (2011) 1796-809.

[66] I. Kubiszewski, C. Cleveland, R. Szostak. Energy return on investment (EROI) for photovoltaic energy. The Encyclopedia of Earth: Boston, USA (2009).

[67] C.J. Cleveland. Net energy from the extraction of oil and gas in the United States. Energy 30 (2005) 769-82.

[68] I. Kubiszewski, C.J. Cleveland, P.K. Endres. Meta-analysis of net energy return for wind power systems. Renewable energy 35 (2010) 218-25.

[69] C.W. King. Energy intensity ratios as net energy measures of United States energy production and expenditures. Environmental Research Letters 5 (2010) 044006. 
[70] C.J. Cleveland. Energy quality and energy surplus in the extraction of fossil fuels in the US. Ecological Economics 6 (1992) 139-62.

[71] M. Cellura, F. Ardente, S. Longo. From the LCA of food products to the environmental assessment of protected crops districts: A case-study in the south of Italy. Journal of environmental management 93 (2012) 194-208.

[72] J. Frorip, E. Kokin, J. Praks, V. Poikalainen, A. Ruus, I. Veermäe, et al. Energy consumption in animal production-case farm study. Agronomy research Biosystem engineering Special 1 (2012) 39-48.

[73] A. Williams, E. Audsley, D. Sandars. Determining the environmental burdens and resource use in the production of agricultural and horticultural commodities: Defra project report is0205. Zu finden in: http://randd defra gov uk/Default aspx (2006). [74] Office of Energy Efficiency \& Renewable Energy. National alliance for advanced biofuels and bioproducts (naabb) synopsis final report. January 2015)

http://www.energy.gov/eere/bioenergy/downloads/national-alliance-advanced-biofuelsand-bioproducts-synopsis-naabb-final

[75] Environmental Protection Agency. Monthly biodiesel production report. January 2015) http://www.eia.gov/biofuels/biodiesel/production/biodiesel.pdf

[76] U.S. EPA Office of Air Quality Planning and Standards. Agriculture. January 2016) www.epa.gov/agriculture/ag101/cropmajor.html

[77] M. Huntley. Personnal communication. 2015.

[78] D.E. Canfield, A.N. Glazer, P.G. Falkowski. The evolution and future of earth's nitrogen cycle. Science 330 (2010) 192-6.

[79] J.N. Galloway, A.R. Townsend, J.W. Erisman, M. Bekunda, Z. Cai, J.R. Freney, et al. Transformation of the nitrogen cycle: Recent trends, questions, and potential solutions. Science 320 (2008) 889-92.

[80] T.B. Pickens. Pickensplan. January 2016) http://www.pickensplan.com/

[81] J.W. Rickey. Hydro power for the production of aluminum. Transactions of The Electrochemical Society 70 (1936) 185-95.

[82] M. Elimelech, W.A. Phillip. The future of seawater desalination: Energy, technology, and the environment. Science 333 (2011) 712-7.

[83] National Resource Defence Council. America's data centers consuming and wasting growing amounts of energy. Jaunary 2016) http://www.nrdc.org/energy/data-centerefficiency-assessment.asp

[84] M. Prud'homme. Global nitrogen fertilizer supply and demand outlook. Science in China Series C: Life Sciences 48 (2005) 818-26.

[85] W.-Y. Huang. Impact of rising natural gas prices on US ammonia supply. DIANE Publishing2007.

[86] P. Hu, S. Chakraborty, A. Kumar, B. Woolston, H. Liu, D. Emerson, et al. Integrated bioprocess for conversion of gaseous substrates to liquids. Proceedings of the National Academy of Sciences 113 (2016) 3773-8.

[87] R. Sandrea, I. Sandrea. New well-productivity data provides US shale potential insights. Oil \& Gas Journal 112 (2014) 66-77. 
Appendix A: Mass, element, and biomass component balances. (AFDW - Ash Free Dry Weight, DW - Dry Weight)

\begin{tabular}{|c|c|}
\hline AFDW Concentration at Harvest (g/L) & 0.500 \\
\hline Ash Content at Harvest (g/L) & 0.015 \\
\hline DW Concentration at Harvest (g/L) & 0.515 \\
\hline \multicolumn{2}{|l|}{ AFDW Biomass Composition } \\
\hline Lipid Content (g/g AFDW) & 0.250 \\
\hline Protein \& NA Content (g/g AFDW) & 0.400 \\
\hline Carbohydrate Content (g/g AFDW) & 0.340 \\
\hline Chlorophyll Content (g/g AFDW) & 0.010 \\
\hline Ash Content (g/g AFDW) & 0.000 \\
\hline Carbon Content (g/g AFDW) & 0.500 \\
\hline Nitrogen Content (g/g AFDW) & 0.075 \\
\hline Phosphorus Content (g/g AFDW) & 0.005 \\
\hline DW/AFDW Ratio (-) & 1.031 \\
\hline Carbon Content (g/g DW) & 0.485 \\
\hline Nitrogen Content (g/g DW) & 0.073 \\
\hline Phosphorus Content (g/g DW) & 0.005 \\
\hline Lipid Content (g/g DW) & 0.243 \\
\hline Carbon Content in Lipid (g/g lipid) & 0.700 \\
\hline Nitrogen Content in Lipid (g/g lipid) & 0.000 \\
\hline Phosphorus Content in Lipid (g/g lipid) & 0.000 \\
\hline Protein (\& NA) Content (g/g DW) & 0.388 \\
\hline Carbon Content in Protein (g/g protein) & 0.452 \\
\hline Nitrogen Content in Protein (g/g protein) & 0.180 \\
\hline Phosphorus Content in Protein (g/g protein) & 0.012 \\
\hline Carbohydrate Content (g/g DW) & 0.330 \\
\hline Carbon Content in Carb (g/g carb) & 0.341 \\
\hline Nitrogen Content in Carb (g/g carb) & 0.000 \\
\hline Phosphorus Content in Carb (g/g carb) & 0.000 \\
\hline Chlorophyll Content (g/g DW) & 0.010 \\
\hline Carbon Content in Chl (g/g Chl) & 0.620 \\
\hline Nitrogen Content in Chl (g/g Chl) & 0.060 \\
\hline Phosphorus Content in Chl (g/g Chl) & 0.000 \\
\hline \multicolumn{2}{|l|}{ Cultivation } \\
\hline Carbon Added (kg/day) & $1,066.67$ \\
\hline Nitrogen Added (kg/day) & 134.17 \\
\hline Phosphorus Added (kg/day) & 8.39 \\
\hline Carbon Loss from PBRs \& Ponds (kg/day) & 266.67 \\
\hline Nitrogen Loss (kg/day) & 13.42 \\
\hline Phosphorus Loss (kg/day) & 0.84 \\
\hline
\end{tabular}




\begin{tabular}{|c|c|}
\hline DW Biomass Produced (kg/day) & $1,649.48$ \\
\hline AFDW Biomass Produced (kg/day) & $1,600.00$ \\
\hline Lipid Produced (kg/day) & 400.00 \\
\hline Protein \& NA Produced (kg/day) & 640.00 \\
\hline Carbohydrate Produced (kg/day) & 544.00 \\
\hline Chlorophyll Produced (kg/day) & 16.00 \\
\hline Ash Produced (kg/day) & 49.48 \\
\hline Carbon in Biomass Yield (kg/day) & 764.70 \\
\hline Nitrogen in Biomass Yield (kg/day) & 116.16 \\
\hline Phosphorus in Biomass Yield (kg/day) & 7.68 \\
\hline \multicolumn{2}{|l|}{ Harvesting } \\
\hline Primary Harvesting Efficiency & 0.90 \\
\hline Biomass Lost in Primary Supernatent (kg/day) & 164.95 \\
\hline Secondary Harvesting Efficiency & 0.90 \\
\hline Biomass Lost in Secondary Supernatent (kg/day) & 148.45 \\
\hline Tertiary Harvesting Efficiency & 0.95 \\
\hline Biomass Lost in Tertiary Supernatent (kg/day) & 66.80 \\
\hline Biomass Yield after Harvesting (kg DW/day) & $1,268.14$ \\
\hline Biomass Yield after Harvesting (kg AFDW/day) & $1,230.09$ \\
\hline Overall harvesting Efficiency (kg/day) & 0.77 \\
\hline Lipid Produced (kg/day) & 307.80 \\
\hline Protein\& NA Produced (kg/day) & 492.48 \\
\hline Carbohydrate Produced (kg/day) & 418.61 \\
\hline Nucleic Acid Producted (kg/day) & 12.31 \\
\hline Ash Produced & 38.08 \\
\hline Carbon in Biomass Yield (kg/day) & 588.44 \\
\hline Nitrogen in Biomass Yield (kg/day) & 89.39 \\
\hline Phosphorus in Biomass Yield (kg/day) & 5.91 \\
\hline \multicolumn{2}{|l|}{ Separations } \\
\hline Lipid Recovery Efficiency & 0.95 \\
\hline Biocrude Yield (kg/day) & 292.15 \\
\hline Lipid in Biocrude (kg/day) & 292.15 \\
\hline Protein \& NA in Biocrude (kg/day) & 0.00 \\
\hline Carbohydrate in Biocrude (kg/day) & 0.00 \\
\hline Nucleic Acid in Biocrude (kg/day) & 0.00 \\
\hline Ash in Biocude (kg/day) & 0.00 \\
\hline Biomass in Biocrude (kg/day) & 292.15 \\
\hline Carbon in Biocrude (kg/day) & 204.50 \\
\hline Nitrogen in Biocrude (kg/day) & 0.00 \\
\hline Phosphorus in Biocrude (kg/day) & 0.00 \\
\hline Biomass Yield (kg DW/day) & 977.13 \\
\hline
\end{tabular}




\begin{tabular}{|l|c|} 
Biomass Yield (kg AFDW/day) & 939.05 \\
\hline Lipid in Biomass Yield (kg/day) & 15.65 \\
\hline Protein \& NA in Biomass Yield (kg/day) & 492.48 \\
\hline Carbohydrate in Biomass Yield (kg/day) & 418.61 \\
\hline Nucleic Acids in Biomass Yield (kg/day) & 12.31 \\
\hline Ash in Biomass Yield (kg/day) & 38.08 \\
\hline Carbon in Biomass Yield (kg/day) & 383.94 \\
\hline Nitrogen in Biomass Yield (kg/day) & 89.39 \\
\hline Phosphorus in Biomass Yield (kg/day) & 5.91 \\
\hline
\end{tabular}

